\title{
Numerical modelling of triple-junction tectonics at Karlıova, Eastern Turkey, with implications for regional magma transport
}

\author{
Özgür Karaoğlu ${ }^{1,2, *}$, John Browning ${ }^{2,3}$, Mohsen Bazargan ${ }^{2,3}$, Agust Gudmundsson ${ }^{2}$ \\ ${ }^{1}$ Eskişehir Osmangazi University, Department of Geological Engineering, 26040 Eskişehir, \\ Turkey \\ ${ }^{2}$ Department of Earth Sciences, Royal Holloway University of London, Egham, TW20 0EX, \\ $\mathrm{UK}$ \\ ${ }^{3}$ Department of Earth Sciences, University College London, Gower Street, London WC1E \\ 6BT, UK \\ *Correspondence to: Ö. Karaoğlu, ozgur.karaoglu@deu.edu.tr; ozgur.karaoglu@rhul.ac.uk
}

\section{Abstract}

Few places on Earth are as tectonically active as the Karlova region of eastern Turkey. In this region, complex interactions between the Arabian, Eurasian and Anatolian plates occur at the Karliova Triple Junction (KTJ). The relationship between tectonics and magma propagation in triple-junction tectonic settings is poorly understood. Here we present new field and numerical results on the mechanism of magma propagation at the KTJ. We explore the effects of crustal heterogeneity and anisotropy, in particular the geometry and mechanical properties of many faults and layers, on magma propagation paths under a variety of tectonic loads. We propose that two major volcanic centres in the area, the Turnadag volcano and the Varto caldera, are both fed by comparatively shallow magma chambers at depths of about $8 \mathrm{~km}$, which, in turn, are fed by a single, much larger and deeper reservoir at about $15-18 \mathrm{~km}$ depth. By contrast, the nearby Özenç volcanic area is fed directly by the deeper reservoir. We present a series of two-dimensional and three-dimensional numerical models showing that the present tectonic stresses encourage magma-chamber rupture and dyke injection. The results show that inversion tectonics encourages the formation of magma 
paths as potential feeder dykes. Our three-dimensional models allow us to explore the local stresses induced by complex loading conditions at the Karlıva triple junction, using an approach that can in future be applied to other similar tectonic regions. The numerical results indicate a great complexity in the potential magma (dyke) paths, resulting from local stresses generated by interaction between mechanical layers, major faults, and magma chambers. In particular, the results suggest three main controls on magma path formation and, eventual eruptions, at KTJ: (1) the geometry and attitude of the associated faults; (2) the heterogeneity and anisotropic of the crust; and (3) mechanical (stress) interactions between deep and shallow magma chambers.

Key words: triple-junction tectonics, numerical modelling, dyke propagation, Eastern Turkey

\section{Introduction}

One fundamental problem concerning convergent plate boundary tectonics is the nature of the interplay between deformation processes and magma transport (e.g. Hutton, 1988; Vigneresse, 1999). Networks of fractures (primarily extension fractures but also faults) and contacts play a crucial role in creating efficient paths through which magma is transported, stored and eventually erupted at the surface (e.g. Clemens and Mawer, 1992; Cembrana and Lara, 2009). Extrusion-block tectonic regimes may be characterised by triple-junction tectonics with significant components of mostly active strike-slip faulting. These regimes provide a good opportunity to understanding of the interplay between crustal stresses and magma propagation in strike-slip regimes.

7 A triple junction, defined as a boundary where three lithospheric plates meet, marks an important type of setting for extrusion tectonics, initiation of volcanism, and seismicity at 
active plate margins. (cf. Jarosinski, 2012). Triple-junctions are the sites of abundant seismicity, high heat flow, and volcanism (e.g. Furlong and Schwartz, 2004). Although 16 types of possible triple junctions have been identified (McKenzie and Parker, 1967), the spatial and temporal relationships between magmatism and the extrusion tectonics of triple junctions remain poorly constrained. A Karlova-type triple junction, the focus of this study, is a continental triple junction (Şengör et al., 2004) consisting of a non-subductable continental crust. Convergence is predominantly accommodated by strike-slip faults resulting in extrusion tectonics (Şengör et al., 2004).. The new data and numerical model results presented here offer excellent opportunities to clarify and constrain better the relationships between volcanism and tectonic activity at continental triple junctions.

Migration of an extruded block promotes crustal thinning of thickened accretionary complex crust composed of a variety of materials (e.g. Furlong and Schwartz, 2004). Suitably stressed crustal materials of the extruded block on the Karlova-type triple junctions are potential regions for magma ascent. Magma in the mantle and partly in the lower crust ascends by porous flow. At shallower crustal levels, magma ascends primarily through magma-driven fractures, mostly dykes. Dyke initiation and propagation is known to be partly controlled by regional stress fields (Tibaldi, 2015), particularly those induced by crustal extension (e.g. Gudmundsson, 1990; Hurwitz, 2009; Daniels et al., 2012; Le Corvec et al., 2013; Maccaferri et al. 2014).

Magma chambers are the main sources for major polygenetic volcanoes and, partly, for associated volcanic systems, that is, swarms or fields of volcanic (and in rift zones, also tectonic) fissures and basaltic lava flows. The depths of shallow or upper-crustal magma chambers are commonly between $1 \mathrm{~km}$ and $6 \mathrm{~km}$, particularly at divergent plate boundaries (Gudmundsson, 2012). However, some chambers reach depths of 7-9 km, depending on the tectonic regime and crustal structure, and may also be regarded as comparatively shallow 
64 (Chaussard and Amelung, 2014). Chambers at greater depths are normally classified as deepseated reservoirs, and these may reach depths of 20-30 km or more (Gudmundsson, 2012; Chaussard and Amelung, 2014; Le Corvec et al., 2015).

As is detailed below, we propose the existence of two comparatively shallow magma chambers at around $8 \mathrm{~km}$ depth and a deep-seated reservoir at around $15 \mathrm{~km}$ depth in the KTJ region (Figs. 1, 2). We relate these magma sources to likely magma paths, i.e dykes. For an eruption to occur, the magma chamber must rupture (Browning et al., 2015) and propagate a dyke or an inclined sheet to the surface (Gudmundsson, 2012; Chestler and Grosfils, 2013; Le Corvec et al., 2013; Caricchi et al., 2014). The conditions for magma-chamber rupture and dyke injection have been analysed by many (e.g. Gudmundsson, 1990, 2006; Grosfils, 2007; Hurwitz et al., 2009; Gerbault, 2012; Le Corvec et al., 2015). Many of the basic ideas are reviewed and analysed by Gudmundsson (2012), with particular reference to direct observations of fossil magma chambers and the results of hydraulic fracture stress measurements in drill-holes worldwide down to crustal depths of about $9 \mathrm{~km}$.

Generally, the critical stress required for magma-chamber rupture can be reached in two ways (Gudmundsson, 1990, 2006; Folch and Marti, 1998; Browning et al., 2015): (1) by increasing the total pressure inside the chamber (for example, by adding magma to the chamber or through gas exsolution from its magma), and (2) by external extension, such as in rift zones, where divergent plate movements gradually reduce the minimum principal compressive stress $\sigma_{3}$. Tensile fractures do not normally extend to depths greater than $0.5-1$ $\mathrm{km}$. If they try to propagate to greater depths they will change into closed normal faults, in accordance with Griffith criterion (Gudmundsson, 2011). There are thus no open tension fractures or open normal faults at the depth of many kilometres ready to be filled with magma to form dyke fractures. By contrast, dyke fractures are initiated when the excess pressure in the chamber reaches the host-rock tensile strength under either loading condition. Then the 
magma chamber ruptures and a dyke (or an inclined sheet) is injected (Gudmundsson, 1990; Gaffney et al., 2007). The mechanical layering and local state of stress inside the volcano, together with rate of magma solidification and other factors, ultimately determine whether the dyke propagates to the surface and erupts or, alternatively, becomes arrested at depth in the volcano (e.g. Spence et al., 1987; Gudmundsson, 1990, 2011; Acocella and Neri, 2009; Geshi and Neri, 2014 ).

Although the geometries of magma chambers vary, many and perhaps most crustal magma chambers are sill-like (Gudmundsson, 1990; Annen and Sparks, 2002; Kavanagh et al., 2006; Grosfils et al., 2015) as evidenced by seismic studies of volcanoes and rift zones (Sinton and Detrick, 1992) and field studies of fossil chambers, that is, plutons (Pasquarè and Tibaldi, 2007; Tibaldi et al., 2008; Gudmundsson, 2012). Numerical, analogue, and field studies indicate that piston-type calderas are often associated with a sill-like magma chambers (Geyer et al., 2006; Geyer and Marti, 2009; Gerbault, 2012; Gregg et al., 2012, 2015; Le Corvec et al., 2013; Gudmundsson, 2015). The size of an underlying shallow magma chamber is then thought to closely resemble the radius of associated collapse caldera, whereas the deeper reservoirs may be many times larger (Gudmundsson, 2012, 2015; Grebault, 2012; Gregg et al., 2013; Grosfils, 2007, 2015; Browning and Gudmundsson, 2015). As indicated above, the depths of many magma chambers have been estimated using petrological, geochemical, and geophysical methods (Becerril et al., 2013; Chaussard and Amelung, 2014).

The emplacement of hot asthenospheric mantle to shallow levels beneath a Karlovatype triple junction could be expected to generate melt and, likely, surface volcanism. Consistent with this expectation is the sequence of volcanic centres that have erupted in the 
wake of the triple junction within the Karlıova regime (e.g. Furlong and Schwartz, 2004; Gaffney et al., 2007).

This study focuses on the mechanism of magma propagation, primarily through dykes, in the Karlova Triple Junction (KTJ) tectonic regime. We aim to demonstrate how fault geometry and mechanical properties may affect magma propagation under a variety of tectonic boundary loads. We discuss the geologic setting of the KTJ and the manifestations of shallow and deeper magma chambers within the crustal segment. Our numerical modelling aims to quantify the crustal response to various tectonic regimes in Eastern Turkey. The region is characterised by considerable lithological heterogeneity and anisotropy (cf. Jarosinski, 2012) which are taken into account in our numerical models. We present a series of two-dimensional and three-dimensional numerical models to help constrain evolving ideas regarding the tectonics of the KTJ. We also analyse a north-south striking profile that is subject to regional compression and local extensional tectonic phases which likely operated in the region $\sim 3 \mathrm{My}$. A general three-dimensional model is presented to show the local stress effects resulting from complex regional loading on crustal magma chambers.

\section{Geologic and tectonic setting}

Eastern Turkey is a part of the Mediterranean region which is characterised by the presence of major continental fragments and suture zones (Şengör et al., 2004). Propagation of the westward extrusion of the Anatolian block, just after the formation of the Northern Anatolian Fault Zone (NAFZ), started around $12 \mathrm{Ma}$ from the pivot point of KTJ and triggered lithosphere-scale transtensional deformation (Barka, 1992; Şengör et al., 2004). The NAFZ, whose main fault is the active right-lateral North Anatolian Fault (NAF), is a nearly $2000 \mathrm{~km}$ long zone, extending from Karlıova in eastern Anatolia to the tip of the Corinth Rift 
in Greece (Armijo et al., 1999). The overall width of NAFZ increases from 10 km (Figs. 1, 2) in the east to $\sim 100 \mathrm{~km}$ in the west (Şengör et al., 2004).

Present-day earthquake focal-mechanism solutions indicate dextral transtensional movements (McKenzie, 1972; Ozener et al., 2010) on the Yedisu Fault at the western part of the KTJ (Fig. 1). GPS data show that the eastern part of the Anatolian plate (the western part of the KTJ) moves at a rate of $\sim 20 \mathrm{~mm} / \mathrm{yr}$ with respect to the Eurasian plate (Fig.1, McClusky et al., 2000; Reilinger et al., 2006). Solid-block modelling of the region and GPS velocity data (Fig. 1) show that eastern margin of the KTJ is undergoing crustal shortening, whereas in the west the prevailing tectonic stress and crustal deformation is transtensional to the west (Barka, 1992; Aktug et al., 2013). The present geodetic average slip rate for Eastern Anatolian Fault Zone (EAFZ) is $5 \mathrm{~mm} / \mathrm{yr}$ (Aktug et al., 2013). The EAFZ is around 30-kmwide at the eastern extremity near the KTJ. It is proposed that the fault zone has been active since the Pliocene (Tatar et al., 2004).

The NAFZ and EAFZ, which are two western branches of the KTJ, are characterised by transtensional tectonics (Şengör et al., 2004). The right-lateral Yedisu Fault (YS, Fig. 1), striking $\mathrm{N} 105^{\circ} \mathrm{E}$, represents the eastern branch of the NAFZ and extends for more than $30 \mathrm{~km}$ to the KTJ (Fig. 1). The VFZ extends for over $50 \mathrm{~km}$, strikes $\mathrm{N} 105^{\circ} \mathrm{E}-\mathrm{N} 120^{\circ} \mathrm{E}$ and can be subdivided into six fault segments (Sançar et al., 2015). The Varto Fault (VF, Fig. 2c) is seismically the most active segment of the VFZ; it is a $\mathrm{N} 120^{\circ} \mathrm{E}$-striking right-lateral strikeslip fault with a reverse component that offsets the southern part of the Varto caldera. Two destructive earthquakes ( $\mathrm{Mw}=6.8$ and 6.2) occurred on the VFZ in 1966 (Fig. 2c, Ambraseys and Zatopek, 1968). Karaoğlu et al. (in press) suggest that the combined motions of NW-striking dextral, normal, oblique and thrust faults indicate a successive and reactive 
tectonic phase that caused incremental complex movement of numerous fault blocks during the deformation of the Karlıova and Varto region since 6 Ma.

Structural and stress data indicate a distinct kinematic behaviour of the KTJ during the past 12 Ma (Şengör et al., 2004). Following the formation of NAFZ and EAFZ, the western part of the triple junction has been subject to transtensional tectonics during which the east end of the KTJ has undergone incremental deformation accommodated by numerous faults during (i) ongoing shortening phases driven by the regional-scale thrust tectonic regime and (ii) transtensional phase caused by westward extrusion tectonics at a local-scale (Karaoğlu et al., in press). It has been suggested that a right-lateral motion developed under a NE-SW-trending extension associated with NW-SE contraction. The fault surface planes of the WNW-ESE-striking VFZ were reactivated at $3 \mathrm{Ma}$, which suggests that inversion tectonics occurred when transtensional faults reversed their movement during a subsequent compressional tectonic episode (e.g. Williams et al., 1989). Since 3 Ma, thrusting shifted further south, coupled with a component of dextral strike-slip motion (Karaoğlu et al., in press).

Volcanic activity commenced on the EAF with some eruptions producing acidic rocks whose ages are between 4.4 and 6.06 Ma (Poidevin et al., 1998). The earliest volcanism occurred at around $6 \mathrm{Ma}$ and highlights the initiation of crustal deformation in the EAF. As for the deformation of Varto and Turnadağ volcanoes, the age of the basement volcanic rocks in the southern part of Varto is around $3 \mathrm{Ma}$ (Fig. 2a). The lifespan of the Varto caldera volcanism is estimated at between 3 and $1 \mathrm{Ma}$ (Hubert-Ferrari et al., 2009). This may be regarded as the second major volcanic episode in the area. The third event or activity in the area relates to some small-scale volcanism on the southern sector of the VFZ. The resulting domes are dated at approximately $0.73 \mathrm{Ma}$ to $0.46 \mathrm{Ma}$ (Fig. 2a). The most recent dyke-fed 
eruptive and effusive-type volcanism (1.96-2.67 Ma, based on K/Ar ages from Biggazi et al. 1997, 1998) occurred around the Özenç area, at the southern part of the Varto caldera (Fig. 2). The volcanism produced partly mafic lavas, mostly of the alkaline and rarely sub-alkaline series, including basaltic trachy-andesite and basaltic andesite (Buket and Temel, 1998; Hubert-Ferrari et al., 2009). The Varto caldera, the Turnadağ volcano, and the Özenç volcanic area (Fig. 2) show distinct volcanic facies, and also certain geochemical characteristics (e.g. Buket and Temel, 1998; Hubert-Ferrari et al., 2009; Sançar et al., 2015).

\section{Magma-chamber geometry}

In order to estimate the rough geometry and depth of the magma chamber feeding a polygenetic volcano, field and analytical data are required. There have not, however, been any petrological or geodetic studies on the geometry of the magma feeding systems in Eastern Turkey. Recent compilations, based on various methods, suggest that most magmachamber or reservoir depths worldwide range from about $1 \mathrm{~km}$ to about $20 \mathrm{~km}$ below the volcanoes to which they supply magma (Middlemost, 1997; Gudmundsson, 2012; Chaussard and Amelung, 2014; Tibaldi, 2015). The exact depths of the magma chambers for the volcanoes Turnadağ and Varto (Fig. 2b), as well as for the Özenç volcanic area, are not known. The chemistry of the eruptive materials suggest that the source chamber for the Özenç volcanism is deeper and larger than the chambers beneath Turnadağ and Varto. All these areas, however, contain dykes whose aspect (length/thickness) ratios can be used to estimate the depths of the source chambers.

We use a method based on the principles of fracture mechanics and fluid-dynamics to constrain the depth of the magma chambers/reservoirs at Karlıova (e.g. Becerril et al., 2013). All dykes in the area are dominantly trachy-basaltic in composition. Magma overpressure $\left(p_{o}\right)$ within a dyke during its formation can be estimated from the ratio of dyke strike dimension 
$(L)$ and thickness $\left(\Delta u_{I}\right)$. A total of 14 dyke measurements in the study area were used to

207

208

210 estimate their depth of the source chamber/reservoir. The method is as follows. The opening displacement of an elastic mode I (tensile mode) crack, such as a dyke, subject to internal fluid or magma overpressure (driving pressure) $p_{o}$ is given by:

$$
\Delta u_{I}=\frac{2 p_{o}\left(1-v^{2}\right) L}{E}
$$

where $L$ is the smaller of the strike and dip dimensions of the fracture, and $E$ and $v$ are Young's modulus and Poisson's ratio, respectively, of the host rock. While $\Delta u_{I}$ denotes the opening or aperture of the dyke at its time of emplacement it also corresponds roughly to the thickness of a solidified dyke as measured in the field (the error due to contraction as the magma as the dyke solidifies is about $10 \%$ - Becerril et al., 2013). Here we use $40 \mathrm{GPa}$ as an average Young's modulus for the host rock and 0.25 for the Poisson's ratio. The overpressure in a dyke at the crustal level of exposure (at the surface for a feeder) is given by

$p_{o}=p_{e}+\left(\rho_{r}-\rho_{m}\right) g h+\sigma_{d}$

where $p_{e}$ is the fluid excess pressure in the source magma chamber, $\rho_{r}$ is the average density of the host rock, $\rho_{\mathrm{m}}$ is the average density of the magma in the dyke, $g$ is acceleration due to gravity, $h$ is the dip-dimension or height of the dyke, and $\sigma_{d}$ is the differential stress (the difference between the vertical stress and the minimum principal horizontal stress) at the depth in the crust where the dyke is measured or, for a feeder-dyke, the stress difference at the surface where the volcanic fissure forms. From equations (1) and (2) the depth to the intersection between the source magma chamber and the feeder dyke is:

$$
h=\frac{\Delta u_{I} E}{2 L\left(1-v^{2}\right)\left(\rho_{r}-\rho_{m}\right) g}-\frac{p_{e}+\sigma_{d}}{\left(\rho_{r}-\rho_{m}\right)}
$$



the three volcanic regions under consideration (Fig. 1). We use the typical trachy-basaltic magma density $\left(\rho_{m}\right)$ of $2730 \mathrm{~kg} . \mathrm{m}^{-3}$ (e.g. Middlemost, 1997). Since there are no detailed and accurate density data for the crust of the Eastern Anatolia Accretionary Complex, we have used a revised geological stratigraphy made of 18 lithologic units (Appendix 1), of the region (e.g. Tarhan, 1991). The crust is thought to be mostly composed of units of limestone, metamorphic rocks, massive gabbro and sandstone with estimated laboratory densities in the range from about 2000-3100 $\mathrm{kg} \mathrm{m}^{-3}$ (e.g. Gudmundsson, 2011). We use an average density of $2650 \mathrm{~kg} \cdot \mathrm{m}^{-3}$. Note that excess magma pressure in the chamber/reservoir $\left(p_{e}\right)$ is defined as pressure in excess of lithostatic stress or pressure and thus automatically takes into account the effects of gravitational loading (e.g. Gudmundsson, 2011, 2012).

The measured feeder-dyke thicknesses range from 0.8 to $3 \mathrm{~m}$. The estimated overpressures from Eq. (1) are from 9 to $11 \mathrm{MPa}$ for the Varto and Turnadağ volcanoes and from 15 to $18 \mathrm{MPa}$ for the Özenç volcanic area (flood basalts). These are similar overpressures as estimated for dykes in many other areas (e.g., Becerril et al., 2013). Using these and the above values, Eq. (3) yields source-chamber depths of 8-10 km for Varto and Turnadağ volcanoes, and 15-18 km for the Özenç volcanic area (Appendix 2). In the numerical models we thus use an estimated depth of $8 \mathrm{~km}$ for the magma chambers feeding eruptions in volcanoes of Varto and Turnadağ and $15 \mathrm{~km}$ for the larger reservoir supplying magma to the flood basalts of the Özenç volcanic area.

\section{Model set-up}

All the numerical models are built and solved using the finite element program COMSOL (www.comsol.com; cf. Zienkiewicz, 1979; Deb, 2006; Tabatabaian, 2014). The models are based on the real geological setting of the KTJ as interpreted from field 
measurements and seismic data (e.g. Sandvol et al., 2003) as well as InSAR data (Cavalié and

252

253

254 Jónsson, 2014). We differentiate between two predominant magma-chamber modelling techniques. The first uses 2-D geometry where magma chambers are modelled as holes with applied excess pressure $\left(p_{e}\right)$ (Gudmundsson, 2006, 2011; Gerbault, 2012; Gerbault, 2012). The second set uses 3-D geometry where the chambers/reservoirs are modelled as ellipsoids of prescribed volume with applied excess pressure. We present two geometries of 2-D models based upon (1) a N-S striking profile through the Varto caldera (Fig. 2), and (2) an E-W striking profile that encompasses both the Turnadağ volcano to the west and the Varto caldera to the east.

Our models consider ellipsoidal magma chambers/reservoirs. While these are, in detail, simplifications of the actual shapes, the long-term stable geometries may be similar to these (e.g. Gudmundsson, 2012). Topography may affect near-surface stress fields. However, in the present models the primary focus is on the local stresses induced by the stress concentration around chambers/reservoirs subject to different boundary conditions, in which case topography normally plays a less prominent role (cf. Gaffney and Damianac, 2006; Gudmundsson, 2006). Thus, we assume a flat topography in all models. The 16 different mechanical layers used in our models are based on our direct geological observations. The values used to calculate magma chamber depth encompass all of these mechanical layers.

In Fig. 3 we show only the N-S model setup. In this model two magma chambers, one relatively shallow, at a depth of $8 \mathrm{~km}$, and one deeper, at a depth of $15 \mathrm{~km}$, are residing within a heterogeneous, anisotropic elastic half space with Young's modulus (E) varying between individual layers from $40 \mathrm{GPa}$ to $0.1 \mathrm{GPa}$, as shown in Fig. 2. The shallower magma chamber has a maximum diameter of $9 \mathrm{~km}$, whereas the deeper chamber or reservoir has a maximum diameter of $30 \mathrm{~km}$. Poisson's ratio $(v)$ does not vary significantly between 
individual layers; thus, in the models we use a constant typical value for rocks of 0.25 (Gudmundsson, 2011). In the N-S striking profile all the layers dip gently to the north, whereas the E-W striking profile hosts predominantly horizontal layers. The softest (most compliant) layers are those comprising the fault cores/damage zones $\left(\mathrm{E}_{\text {fault }}\right)$, indicated by black polygons in Fig. 3. The faults are given Young's modulus values of $0.1 \mathrm{GPa}$, as has been estimated for some active faults (Gaffney et al., 2007; Gudmundsson, 2011; Grosfils et al., 2015). The thicknesses of layers and fault cores/damage zones are taken from our geological measurements (Fig. 2) and given in Appendix 1. All 2-D models are fixed at the corners, with boundary loads applied at the left and right edges and a free surface (a region free from shear stress) prescribed on the upper edge. More specifically, the fixing of the models at the corners means that the model boundaries are free to move (be displaced) under loading, except for the corners themselves. This is a standard procedure in modelling magma chambers subject to various loading conditions (e.g. Gudmundsson, 2006, 2011).

Loading conditions applied are (1) internal magmatic excess pressure between 5 and $15 \mathrm{MPa}$, (2) regional extension (tension) of $5 \mathrm{MPa}$, (3) regional compression of $5 \mathrm{MPa}$, and (4) a combination of regional stress and magmatic excess pressure. Magma-chamber rupture and dyke injection is supposed to occur when the tensile stress, mostly measured through hydraulic fracturing and down to crustal depths of about $9 \mathrm{~km}$, are between 0.5 and $9 \mathrm{MPa}$, the most common values being 2-4 MPa (Gudmundsson, 2011). As indicated above, by using excess pressure in the chamber/reservoir, rather than total pressure, the effects of gravity are automatically considered (cf. Gudmundsson, 2012). We use a triangular mesh with a maximum element size of $4.02 \mathrm{~km}$; minimum element size of $0.018 \mathrm{~km}$ for 2-D, and tetrahedral mesh with a maximum element size of $4.02 \mathrm{~km}$; minimum element size of $1.8 \mathrm{~km}$ for 3-D models. 

encompass the regional stress pattern in two dimensions. For this reason we made additional 3-D models that allow more boundary loading options. In contrast to the two-dimensional models, in these 3-D models results can be observed normal to the plane of interest. In the 3D models, we impose three magma chambers of similar depths and sizes to those used in the 2-D models, i.e, two shallow chambers at $8 \mathrm{~km}$ depth and one deeper and larger reservoir at $15 \mathrm{~km}$ depth. The axes (diameters) of the ellipsoidal shallow chambers are $2 \mathrm{~km}, 6 \mathrm{~km}$, and 9 $\mathrm{km}$ (Fig. 2b), similar in general dimensions to many shallow magma chambers (Gudmundsson, 2012). By contrast, the axes of the 4 km, $12 \mathrm{~km}$, and $30 \mathrm{~km}$ (Fig. 2b), and thus similar in geometry and dimensions to many inferred deep-seated reservoirs in rift zones (Gudmundsson, 1990, 2006). All 3-D models simulate an elastic half space with a Young's modulus of $40 \mathrm{GPa}$. In these models the focus is not on the mechanical contrast between individual layers but on the effect of regional stresses on spatial distribution of the local stresses around the magma chambers. The boundary loads prescribed in these 3-D models include (1) compression or extension various directions in relation to the axes of the magma chambers/reservoirs had (2) shear, that is, compression or extension in opposing directions across a zone, thereby simulating strike-slip tectonics.

\section{Results}

318 it is first necessary to consider the stress required for magma chamber rupture. In the simplest 319 terms, a magma chamber will rupture and inject a dyke or an inclined sheet when 320 (Gudmundsson, 1990, 2011): 
where $p_{l}$ is lithostatic pressure and $p_{e}$ is the excess pressure in the magma chamber, $\sigma_{3}$ is minimum principal compressive stress in the host rock, and $T_{\mathrm{o}}$ is the tensile strength of the host rock which, as indicated above, ranges from 0.5 to $9 \mathrm{MPa}$ (cf. Amadei and Stephenson, 1997). When a chamber roof has failed in tension and a dyke is initiated then the magma follows the path or trajectories of maximum principal compressive stress, $\sigma_{l}$ (Gudmundsson, 2011).

\subsection{Magma-chamber excess pressure}

Here we present first the results on crustal stresses induced solely by magmatic excess pressure within each chamber, ignoring initially the potential effects of any regional tectonic loading. In Fig. 4 we show the magnitudes of the minimum principal compressive (maximum tensile), stress, $\sigma_{3}$, and von Mises shear stress, $\tau$. In both the N-S and E-W profiles the maximum tensile and shear stresses concentrate at the lateral margins of each magma chamber and at the earth's surface above the magma chamber. Complex stress patterns and interactions occur at depth because of the attitude and mechanical properties of the imposed fault structures. In all models the soft or compliant material that comprises each fault zone inhibits stresses within the fault, but raises and concentrates stresses at the boundaries or contacts of the faults with the host rock. The effects are, for example, prominent in the steeply dipping East Anatolian Fault (EAF) segment that extends between the shallow and deep chambers along the E-W profile (Figs. 4a, b). At this location (Fig. 4a) high shear stresses concentrate where the fault zone intersects the surface and at depth high tensile stresses occur where the fault zone narrows (Fig. 4c). In the N-S profile, two shallow dipping faults concentrate both shear and tensile stress between the margins of the deep and shallow chambers, indicating that magma transfer between the two systems in this location is likely (Figs. 4a, b). Stress also concentrates at depth along the EAF in the E-W profile (Figs. 4c, d). 

as well) for the loading of the magma chambers/reservoirs. However, in the models presented here we used only $5 \mathrm{MPa}$ as the loading, both as regards the magmatic excess pressure as well as for the external tension (in some of the models). This we did primarily because $5 \mathrm{MPa}$ is similar to the in situ tensile strength of rocks. Increasing the excess magmatic pressure simply increases the stress concentration magnitudes (higher stresses close to the chamber, in particular) but does not markedly change the geometry of the concentration zones and their location - as is well known from numerical modelling in volcanology and other fields (e.g. Gudmundsson, 2011).

\subsection{Regional tectonic stresses}

In the second set of 2-D models the focus is on the effect of regional stresses induced by tectonic loading on the local stresses around the magma chambers. In Fig. 5 we show the tensile and shear stresses around overpressured magma chambers subjected to both regional compression and regional extension, as indicated by arrows in the Fig. 5. During E-W extension of $5 \mathrm{MPa}$, two stiff (high Young's modulus) near-surface units concentrate tensile stress, which may encourage dyke propagation (Gudmundsson, 2006). Focussing on the EAF (Figs. 5e-h), we note that shear stress concentrates at the surface during regional compression but dissipates during imposed regional extension in both strike directions (Figs. 5a, e). The $\mathrm{N}-\mathrm{S}$ striking profile is dominated by a series of high angle faults (Fig. 5a) that during regional compression (Figs. 5a-d) suppress much of the shear stress surrounding the deeper chamber

(Figs. 4b, 5d). The effect is similar during regional extension; however, the steepest central fault concentrates substantial shear stress directly above the central part of the deep chamber. (Figs. 5a, c). 

paths. The effect is most clear in the E-W profile whereby tensile stresses are shifted to the west at the Turnadağ volcano during regional extension. Our findings also indicate an increased likelihood of shallow chamber dyke injection from the deeper source during periods of regional extension.

\subsection{Three-dimensional models}

In order to better understand the geodynamic setting of the Karlova Triple-Junction we present a series of simple three-dimensional (3-D) models (Figs. 6-10) exploring the local stresses in differential tectonic regimes. These models are homogeneous; the aim here is not to fully encompass the geological setting of Karlıva but instead to provide constraints on the location of volcanism as a function of different tectonic loading. In Figs. $6 \mathrm{a}, \mathrm{b}$ in the E-W profile we apply a north-south directional extensional load of $5 \mathrm{MPa}$ and observe the resultant tensile and shear stresses along E-W and N-S profiles. The deeper and shallower chambers concentrate shear stress at their margins. However, those shear stresses dissipate close to the surface, and then the stress state is dominated by the deeper chamber at Earth's free surface (Figs. 6a-d). Maximum tensile stresses concentrate at the lateral margins of all the chambers, which suggests that the chamber walls tend to rupture and dykes become injected at these locations (Figs. 5a-b).

In Figs. 7, 8 and 9, we model the loading effects of strike-slip faulting, using compressional load of $5 \mathrm{MPa}$ on either side of the N-S-striking plane (Fig. 7). Such a regime cannot be represented fully in a two-dimensional model. As in previous models we show the magnitudes of tensile and shear stresses, although now in two directions (Figs. 7-9). We note stress concentrations and linkage between the deeper chamber and the shallow chamber directly above (Varto) (Fig. 7). Surface stresses are dominated by the larger reservoir, and no 
stress interaction occurs with either chamber or the shallow chamber to the west (Figs. 7b, d). There are tensile stress concentrations around, and particularly above and in-between, the chambers and reservoirs of Varto and Özenç (Fig. 7c). This stress concentration between the chamber and the reservoir may promote rupture at the upper margin (the roof) of the reservoir and encourage dyke propagation from the reservoir to the shallow chamber. Furthermore, from the shallow chamber there is a zone of tensile stress concentration all the way to the surface (Fig. 7a), suggesting that the local stress field encourages dyke propagation from the chamber to the surface. While these models only show the stress magnitudes, we also analysed the stress trajectories (the directions of the principal stresses) and these agree with the suggested dyke paths.

We also made a set of three-dimensional models to explore the effect of N-S and E-W directed regional extension. Even though these models do not accurately reflect the exact tectonic regime of the study area, the results are general and should broadly apply to triple junctions worldwide, even regions where biaxial tension might operate (Appendix 3). We note again that there is very little stress interaction between the eastern and western magmatic systems. Whilst magma propagation between the two systems is unlikely, it appears substantially more difficult to envisage linkage or interaction during a compressional regime where tensile stresses are lower in the area between the eastern and western chambers. In the eastern segment, our results indicate an increased likelihood of magma chamber rupture at the lateral margin of each chamber during extensional loading. We find that extensional loading favours central chamber roof rupture and vertical dyke propagation. As indicated in our earlier models (Figs. 5a, e), the precise direction of the dyke propagation path will depend on local stresses related to crustal heterogeneity and anisotropy (layering). However, the extension appears to have shifted the principal stresses towards the north in comparison to the previous models that consider only extension or compression independently. 
In Figs. 8 and 9 we compare the effects different types of shear, that is, left-lateral and

420

421

422

right-lateral strike-slip faulting, on the local stresses, particularly around the magma chambers/reservoirs. The main finding is that the shear and tensile stresses again concentrate around the chambers/reservoirs, but the stresses concentrated around the deep-seated chamber (reservoir) are greater at the surface in the right-lateral simulations (than in the leftlateral simulations, shifting stresses slightly to the east (Fig. 9c). In Fig. 10 we simulate a N-S compressional regime which has the effect of increasing the symmetry of local stresses, and in doing so concentrating both tensile and shear stresses vertically above the deeper magma reservoir.

\section{Discussion}

Over the past decades many studies have focused on understanding better the mechanical principles that control dyke propagation paths through the Earth`s crust (e.g. Druitt and Sparks, 1984; Martí et al., 1994; Acocella et al., 2004; Geyer et al., 2006; Gudmundsson, 2006; Martí et al., 2008; Hurwitz, 2009; Gerbault, 2012; Gudmundsson, 2012; Le Corvec et al., 2013; Karaoğlu, 2014). Although some studies have attempted to understand how faults affect magma ascent (Magee et al., 2014; Browning and Gudmundsson, 2015; Gudmundsson, 2015) many aspects of fault-magma path interactions remain poorly understood. Our work focuses on the mechanism of dyke propagation through a highly heterogeneous, anisotropic, and intensely faulted crust of the KTJ. It is widely accepted that the region has experienced N-S directed crustal shortening. We have also taken into consideration the inversional tectonic regime, i.e., a successive $\mathrm{N}-\mathrm{S}$ directed extension and compression during the past $3 \mathrm{Ma}$, an idea based on the results of recent field studies (Karaoğlu et al., in press). We further accounted for dyke propagation under either E-W compressional, or E-W extensional tectonic regimes (Fig. 4), as well as strike-slip regimes. 
444 by the geometries and depths of magma chambers as well as the local stresses in the

445

446

447 heterogeneous, anisotropic, and faulted crust. The overall process of dyke initiation and propagation may be affected by at least three distinct factors, namely (i) the geometry and attitude of the associated faults; (ii) the heterogeneity and anisotropy of the crust; and (iii) stress concentrations around, and stress (mechanical) interactions between, magma chambers. Here we discuss our numerical analysis of two different tectonic regimes, namely inversion tectonics using N-S and E-W-striking profiles in order to better understand dyke propagation under different stress conditions at the Karlıova-Varto region.

\subsection{Magma transport in the absence of tectonic stresses}

Our numerical models indicate that the mechanical properties of a heterogeneous and anisotropic crust substantially influence the local stresses and thus the potential dyke propagation paths (e.g. Chaussard and Amelung, 2014; Le Corvec et al. 2015) (Fig. 4). The initial stage of dyke propagation is magma-chamber roof rupture leading to the initiation of a dyke (e.g. Clements and Mawer, 1992; Gerbault, 2012). One of the most common reasons for the generation of excess pressure within a shallow magma chamber is likely recharge from parental magma at depth that has accumulated in a deeper reservoir or chamber (e.g. Chestler and Grosfils, 2013). It is only when a sufficient volume of magma accumulates within a shallow chamber that it can reach the conditions of likely rupture (Eq. 4; Browning et al., 2015). Dyke propagation at great depths requires suitable stress interactions between the shallower and the deeper magma chambers or reservoirs (Fig. 4a). Our numerical results show that layering affects local stresses and many aspects of fault-dyke path interactions

(Figs. 4c, d). For all loadings considered (compression, extension, and shear), tensile and 
shear stresses concentrate around, and particularly at the margins of the deep magma chambers (Fig. 4).

While the $4 \mathrm{~km}$ wide EAF is one of the most remarkable structural elements along the

E-W profile (Fig. 4c), the conditions for dyke propagation through and along a fault are only observed at the much smaller VFZ primarily due to the faults orientation and position. However, we note some minor stress accumulation in the EAF (Figs. 4c, d). Tensile stress along the VFZ likely creates favourable conditions for dyke propagation along the previously dissected fault at the northern margin of the deeper reservoir. This result suggests that deep and shallow magma chamber stress interactions may play an important role in dyke propagation which is strongly influenced by faults and other crustal heterogeneities and layering (Fig. 4).

\subsection{Magma transport under regional tectonic stresses}

Magmatic systems evolve partly as a result of tectonic deformation, generally and in the context of processes associated with the KTJ. Recently, this area has experienced N-S directed compression and E-W directed extension (e.g. Aktug et al. 2013). In the E-W profile, shallow dyke injection, some reaching the surface to erupt, appears possible during both extensional and compressional tectonic loading in and around the Varto caldera (Figs. 5e, g). Deep and shallow magma chamber interactions may result in magmatism that becomes partly channelised through the EAF, thereby encouraging volcanic eruptions in the Varto region. Our results demonstrate that fault zones may facilitate magma transport during different tectonic loadings. The effects of these faults on potential magma paths is more prominent for compressional (Figs. 5g, h) than extensional loading (Figs. 5e, f). magma chambers, shear stresses concentrate also above the central parts of the deeper 
chambers/reservoirs (Fig. 5h), as well as at caldera ring-faults (e.g. Annen and Sparks, 2002; Marti et al., 1994). Our models indicate how magma transport and regional tectonics may interact in an intensely fragmented and mechanically layered crust (e.g. Spence et al. 1987; Tibaldi et al., 2008), in particular through the cross faults of the VFZ (Figs. 5b, d). The vertical stress patterns between the two magma chambers observed in the N-S profile support the view that fault zones can act as magmatic paths (Fig. 5d). Even during a $\mathrm{N}-\mathrm{S}$ compressional phase the results suggest that dykes may be injected, resulting in possible dyke injection from the deeper source to the shallow magma chamber (Fig. 5d). In the case of N-S extension (Fig. 6), the youngest fault, which is a normal fault as shown in Fig. 2a, plays a crucial role for shear stress concentration (Figs. 5a-d and Fig. 6). We show that the interaction between these fault systems, of various ages, encourages dyke injection from the central part of a deeper magma reservoir, and therefore acts as a potential vertical dyke path (Fig. 5b).

\subsection{Numerical models in the Karlova geological context}

In the 2-D models, Varto caldera is represented by steeply dipping inward zones of soft material, as is commonly observed in eroded ring-faults of calderas (e.g. Marti et al. 2008; Browning and Gudmundsson, 2015). The Varto caldera is $8 \mathrm{~km}$ in diameter and with a semi-circular shape. The Varto fault is the most seismically active segment of the VFZ, a $\mathrm{N} 70^{\circ} \mathrm{W}$-striking fault that offsets the southern part of the Varto caldera (Fig. 1). Several distinct dyke locations have previously been reported, the dykes being primarily composed of trachy-basalt, both inside and around the Varto caldera. Those dykes mostly display NW-SE, and rarely NE-SW, orientations. Strike orientation values range from $205^{\circ}$ to $300^{\circ}$ with some indicating the presence of cross-cutting (polyphase) dykes. Our numerical results indicate the potential for multi-stage dyke injections during transtensional to compressional tectonic 
phases (e.g. inversion tectonic regime) resulting principal stress rotation (Fig. 5). Although radiometric data of Varto caldera yields ages from 3.1 to 2.6 Ma (Hubert-Ferrari et al., 2009), which might represent the duration of the volcanism, magma propagation in the crust has probably continued up to the latest eruptions, based on our numerical results (Fig. 5). Recent block rotations around the KTJ based on GPS data (Fig. 1) indicate an intense crustal deformation via successive extensional and shear loading (e.g., Le Corvec et al., 2013; 2015). Long-lived volcanic activity is possible at Varto caldera and in the KTJ in general.

Zones of tensile stress concentration indicate potential magma propagation paths from the shallow magma chambers to the surface of Turnadağ volcano (Fig. 5e). Magma transfer under E-W-oriented compression is unlikely (Figs. 5g, h). Dyke-fed eruptions at Turnadağ volcano are most likely when the magma chamber feeding the volcano is subject to an E-Wdirected extension (Fig. 5e). On account of the westward extrusion of the Anatolian plate since $12 \mathrm{Ma}$, an E-W-directed tectonic regime seems most favourable for eruptions in the Turnadağ volcano (Figs. 1, 5e).

In the Özenç volcanic area our numerical models suggest that volcanic activity is more likely under E-W-directed extension than N-S-directed extension, and may occur under E-W-directed compression as well. We indicate that some, perhaps most, of the feeder dykes may have originated from the deeper magma chamber (Figs. 5c, d). In particular, 3-D modelling results suggest that the deeper magma chamber largely controls the local stress field and, thereby, dyke propagation and resultant eruptions (Figs. 7, 8, 9).

Our 3-D models show the potential for subtle changes in magma propagation paths and eventual eruption resulting from the differences in the boundary loads. While all-round extension has the likely effect of shifting volcanism to the south-east (Appendix 3), strike-slip 
the zone of volcanism substantially to the east, depending on the loading direction (Figs. 7, 8, 9). All results show that the most likely paths for dyke propagation to the surface are from the eastern margin of either the deeper chamber or, possibly, the eastern margin of the shallow (Varto) chamber.

\subsection{Relationships between local stress fields in Karlıva and volcanic eruptions}

Studies indicate that most volcanic unrest periods do not culminate in an eruption (Dzurisin, 1991). Only during comparatively rare periods do dykes propagate all the way to the surface and erupt. For eruptions to occur, the local stresses between the source and the surface along the potential dyke path must be uniform, that is, homogenised (Gudmundsson and Philipp, 2006).

Crustal heterogeneity and anisotropy as well as fault attitude and mechanical properties are the main parameters which influence the local stresses and thereby the magma paths (e.g. Gudmundsson and Philipp, 2006; Browning and Gudmundsson, 2015). Our models suggest that, for many loadings, regional tectonic stresses encourage dyke propagation to the surface.

Since the development of the NAFZ and EAFZ, at around 6 Ma, a strike-slip tectonic regime has dominated the province. Westward extrusion of the Anatolian plate led to a stress field suitable for magmatism at the extremity of the KTJ. The wedge extrusion accommodated by high strain encouraged magmatic paths as feeders for the volcanism. The period represented the initiation of the minor volcanic activity caused by major extension at a local scale. The first volcanic activity commenced with regional stress induced by KTJ tectonics at around 3 Ma. The swarm of parallel dykes in the southern part of KTJ, particularly Özenç volcanic area (Fig. 2), show a stress field with $\sigma_{1}$ in a $\mathrm{N}-\mathrm{S}$ direction and $\sigma_{3}$ in the E-W direction (Karaoğlu et al., in press). The strain direction associated with this dyke 
emplacement confirms that volcanism was controlled by a NEE-SWW-trending zone of weakness, particularly in the Özenç volcanic area and at the Turnadağ volcano.

\section{Conclusions}

We document numerical results on the mechanism of magma propagation paths under a variety of tectonic loads in the crust. We particularly explore the relationship between tectonics and magma propagation in the tectonic settings at the Karlıova Triple Junction (KTJ) of Eastern Turkey. The interpretation of our numerical models suggests that Turnadağ volcanism at the western part of the KTJ has been fed by a shallow magma chamber located at about $8 \mathrm{~km}$ depth during E-W extension. Also, that the Varto caldera is fed by a shallow magma chamber at a similar depth. More specifically, the numerical results show that if the region was subject to an $\mathrm{E}-\mathrm{W}$-oriented compressional stress $\left(\sigma_{1}\right)$, then magma propagation and associated volcanic eruptions would most likely come to an end. Magma transfer between the magma chambers of Varto volcano and Özenç volcanic area exhibits complex stress interactions (Figs. 4, 5). The pattern of local stress changes from the eastern part of the triple junction to the western part. Even though the Özenç volcanic area has experienced N-Sdirected compression, inversion tectonics encourage magma propagation through the crust. Hence, loading during inversion tectonics dramatically changes the orientation of $\sigma_{1}$ and affects magma propagation more than the individual extension or compression regimes. Local stresses are dominated by a deep reservoir located at $15-18 \mathrm{~km}$ depth. It is this reservoir that largely controls the potential of injected dykes reaching the surface and, additionally, the locations of the eventual eruptions. Our three-dimensional models, simulating the complex loading conditions at the KTJ triple junction, can be used (with suitable modifications) to advance our understanding of triple junctions worldwide.

\section{Acknowledgements}


587 2014-MİM-B062). Özgür Karaoğlu is supported by The Scientific

588 and Technological Research Council of Turkey (TUBITAK) International Postdoctoral

589 Research Fellowship Programme. Thanks to the Editor, Tamsin Mather, and to the reviewers,

590 Alessandro Tibaldi and Nicolas Le Corvec, for very helpful comments which greatly

591 improved the paper.

592

593

594

595

596

597

598

599

600

601

602

603

604 
606

607

608

609

610

611

612

613

614

615

616

617

618

619

620

621

622

623

624

625

Acocella, V., Funiciello, R., Marotta, E., Orsi, G., de Vita, S., 2004. The role of extensional structures on experimental calderas and resurgence. J. Volcanol. Geoth. Res. 129 3), 199-217.

Acocella, V., Neri, M., 2009. Dike propagation in volcanic edifices: overview and possible developments. Tectonophysics 471 (1), 67-77.

Aktug, B., Dikmen, Ü., Dogru, A., Ozener., H., 2013. Seismicity and strain accumulation around Karlıova Triple Junction (Turkey). J. Geodyn. 67, 21-29.

Ambraseys, N.N., Zatopek, A., 1968. The Varto Ustukran earthquake of 19 August 1966. B. Seismol Soc. Am. 58, 47-102.

Annen, C., Sparks, R.S.J., 2002. Effects of repetitive emplacement of basaltic intrusions on the thermal evolution and melt generation in the crust. Earth Planet. Sci. Lett. 203, 937-955.

Amadei, B., Stephansson, O., 1997. Rock stress and its measurement. Chapman Hall, New York.

Armijo, R., Meyer, B., Hubert-Ferrari, A., Barka, A.A., 1999. Propagation of the North Anatolian Fault into the Northern Aegean: Timing and Kinematics. Geology 27, 267270.

Barka, A.A., 1992. The North Anatolian fault zone. Ann. Tecton. 6, 164-195.

Becerril, L.,Galindo, I., Gudmundsson, A., Morales, J.M., 2013. Depth of origin of magma in eruptions. Sci. Rep. 3, 2762. http://doi.org/10.1038/srep02762. 
Browning, J., Gudmundsson, A., 2015. Caldera faults capture and deflect inclined sheets: an alternative mechanism of ring dike formation. B. Volcanol. 77 (1), 1-13.

Browning, J., Drymoni, K., Gudmundsson, A., 2015. Forecasting magma-chamber rupture at Santorini Volcano, Greece. Sci. Rep. 5, 15785. http://doi.org/10.1038/srep15785.

Buket, E., Temel, A., 1998. Major-element, trace element, and Sr-Nd isotopic geochemistry and genesis of Varto (Muş) volcanic rocks, Eastern Turkey. J. Volcanol. Geotherm. Res. 85, 405-422.

Caricchi, L., Annen, C., Blundy, J., Simpson, G., Pinel, V., 2014. Frequency and magnitude of volcanic eruptions controlled by magma injection and buoyancy. Nat. Geosci. 7 (2), 126-130.

Cavalié, O., Jónsson, S., 2014. Block-like plate movements in eastern Anatolia observed by InSAR. Geophys. Res. Lett. 41, 26-31.

Chaussard, E., F. Amelung, F. 2014. Regional controls on magma ascent and storage in volcanic arcs, Geochem. Geophys. Geosyst. 15, doi:10.1002/2013GC005216.

Chestler, S.R., Grosfils, E.B., 2013. Using numerical modeling to explore the origin of intrusion patterns on Fernandina volcano, Galápagos Islands, Ecuador. Geophys Res. Lett. 40 (17), 4565-4569.

Clemens, J.C., Mawer, C.K., 1992. Granitic magma transport by fracture propagation. Tectonophysics 204, 339-360.

Daniels, K.A., Kavanagh, J.L., Menand, T., Stephen, J.S.R., 2012. The shapes of dikes: Evidence for the influence of cooling and inelastic deformation. Geol. Soc. Am. Bull. 124 (7-8), 1102-1112. 
648

649

650

651

652

653

654

655

656

657

658

659

660

661

662

663

664

665

666

667

668

Deb, D., 2006. Finite Element Method, Concepts and Applications in Geomechanics. PHI Learning Private Limited, New Delhi.

Druitt, T.H., Sparks, R.S.J., 1984. On the formation of calderas during ignimbrite eruptions. Nature 310, 679-681.

Dzurisin, D., 2006. Volcano deformation: new geodetic monitoring techniques. Springer Verlag, Berlin.

Folch, A., Marti, J., 1998. The generation of overpressure in felsic magma chambers by replenishment. Earth Planet. Sci. Lett. 163 (1), 301-314.

Furlong, K.P., Schwartz, S.Y., 2004. Influence of the Mendocino triple junction on the tectonics of coastal California. Annu. Rev. Earth Planet. Sci. 32, 403-433.

Gaffney, E.S., Damjanac, B., 2006. Localization of volcanic activity: Topographic effects on dike propagation, eruption and conduit formation. Geophys. Res. Lett. 33, L14313, doi: 10.1029/2006GL026852.

Gaffney, E.S., Damjanac, B., Valentine, G.A., 2007. Localization of volcanic activity: 2. Effects of pre-existing structure. Earth Planet. Sci. Lett. 263 (3), 323-338.

Gerbault, M., 2012. Pressure conditions for shear and tensile failure around a circular magma chamber; insight from elasto-plastic modelling. Geol. Soc. (Lond.) Spec. Publ. 367 (1), 111-130.

Gerbault, M., Cappa, F., Hassani, R., 2012. Elasto-plastic and hydromechanical models of failure around an infinitely long magma chamber. Geochem. Geophys. Geosyst, 13 (3). 
669 Geshi, N., Neri, M., 2014. Dynamic feeder dyke systems in basaltic volcanoes: the

670

671

672

673

674

675

676

677

678

679

680

681

682

683

684

685

686

687

688

689 exceptional example of the 1809 Etna eruption (Italy). Front. Earth Sci. 2: 13. doi: 10.3389/feart.2014.00013

Geyer, A., Marti, J., 2009. Stress fields controlling the formation of nested and overlapping calderas: implications for the understanding of caldera unrest. J. Volcanol. Geoth. Res. 181, 185-195.

Geyer, A., Folch, A., Martí, J., 2006. Relationship between caldera collapse and magma chamber withdrawal: an experimental approach. J. Volcanol. Geoth. Res. 157 (4), $375-386$.

Gregg, P.M., De Silva, S.L., Grosfils, E.B., Parmigiani, J.P., 2012. Catastrophic calderaforming eruptions: Thermomechanics and implications for eruption triggering and maximum caldera dimensions on Earth. J. Volcanol. Geotherm. Res. 241, 1-12.

Gregg, P.M., de Silva, S.L., Grosfils, E.B., 2013. Thermomechanics of shallow magma chamber pressurization: Implications for the assessment of ground deformation data at active volcanoes. Earth Planet. Sci. Lett. 384, 100-108.

Gregg, P.M., Grosfils, E.B., de Silva, S.L., 2015. Catastrophic caldera-forming eruptions II: The subordinate role of magma buoyancy as an eruption trigger. J. Volcanol. Geotherm.Res. 305, 100-113.

Grosfils, E.B., 2007. Magma reservoir failure on the terrestrial planets: Assessing the importance of gravitational loading in simple elastic models. J. Volcanol. Geotherm. Res. 166 (2), 47-75. 
Grosfils, E.B., McGovern, P.J., Gregg, P.M., Galgana, G.A., Hurwitz, D.M., Long, S.M., Chestler, S.R., 2015. Elastic models of magma reservoir mechanics: a key tool for investigating planetary volcanism. Geol. Soc. (Lond.) Spec. Publ. 401 (1), 239-267.

Gudmundsson, A., 1990. Emplacement of dikes, sills and crustal magma chambers at divergent plate boundaries. Tectonophysics 176, 257-275.

Gudmundsson, A., 2006. How local stresses control magma-chamber ruptures, dyke injections, and eruptions in composite volcanoes. Earth-Sci. Rev. 79, 1-31.

Gudmundsson, A., 2011. Rock Fractures in Geological Processes. Cambridge University Press, Cambridge.

Gudmundsson, A., 2012. Magma chambers: formation, local stresses, excess pressures, and compartments, J. Volcanol. Geoth. Res. 237-238, 19-41.

Gudmundsson, A., 2015. Collapse-driven large eruptions. J. Volcanol. Geotherm. Res. 304, $1-10$.

Gudmundsson, A., Philipp, S.L., 2006. How local stress fields prevent volcanic eruptions. J. Volcanol. Geoth. Res. 158, 257-268.

Hubert-Ferrari, A., King, G., Woerd, J., Van der, Villa, I., Altunel, E., Armijo, R., 2009. Long-term evolution of the North Anatolian Fault: new constraints from its eastern termination. Geol. Soc. (Lond.) Spec. Publ. 311 (1), 133-154.

Hurwitz, D.M., Long, S.M., Grosfils, E.B., 2009. The characteristics of magma reservoir failure beneath a volcanic edifice. J. Volcanol. Geotherm. Res. 188 (4), 379-394. 
Hutton, D.H., 1988. Granite emplacement mechanisms and tectonic controls: inferences from deformation studies. Transactions of the Royal Society of Edinburgh. Earth Sci. 79 (2-3), 245-255.

Jarosinski, M., 2012. Compressive deformations and stress propagation in intracontinental lithosphere: Finite element modelling along the Dinarides-East European Craton profile. Tectonophysics 526-529, 24-41.

Karaoğlu, O., 2014. Tectonic controls on the Yamanlar volcano and Yuntdagi volcanic region, western Turkey: implications for an incremental deformation. J. Volcanol. Geoth. Res. 274, 16-33.

Karaoğlu, Ö., Sağlam-Selçuk, A., Gudmundsson, A. (in press). Tectonic controls on the Karlıova Triple Junction (Turkey): implications for tectonic inversion and the initiation of volcanism. Tectonophysics.

Kavanagh, J.L., Menand, T., Sparks, R.S.J., 2006. An experimental investigation of sill formation and propagation in layered elastic media. Earth Planet. Sci. Lett. 245, 799813.

Le Corvec, N., Menand, T., Lindsay, J., 2013. Interaction of ascending magma with pre-existing crustal fractures in monogenetic basaltic volcanism: an experimental approach. J. Geophys. Res-Sol Ea. 118 (3), 968-984.

Le Corvec, N., McGovern, P.J., Grosfils, E.B., Galgana, G., 2015. Effects of crustal-scale mechanical layering on magma chamber failure and magma propagation within the Venusian lithosphere. J. Geophys. Res. 120 (7), 1279-1297. 
Maccaferri, F., Rivalta, E., Keir, D., Acocella, V., 2014. Off-rift volcanism in rift zones determined by crustal unloading. Nat. Geosci. 7 (4), 297-300.

Martí, J., Ablay, G.J., Redshaw, L.T., Sparks, R.S.J., 1994. Experimental studies of collapse calderas. J. Geol. Soc. London 151, 919-929.

Martí, J., Geyer, A., Folch, A., Gottsmann, J., 2008. A review on collapse caldera modelling. In: Gottsmann, J., Martí, J. (Eds.), Caldera Volcanism: Analysis, Modelling and Response. Development in Volcanology. Elsevier, Amsterdam, vol.10, pp.233-283.

McClusky, S. et al., 2000. GPS constraints on plate motion and deformation in the eastern Mediteranean: Implication for plate dynamics, J Geophys Res. 105, 5695-5719.

McKenzie, D., 1972. Active Tectonics of the Mediterranean Region, Geophys J Roy Astr S. $30,109-185$.

McKenzie, D.P., Parker, R.L., 1967. The North Pacific: an example of tectonics on a sphere. Nature 216, 1276-1280.

Middlemost, E.A., 1997. Magmas, Rocks and Planetary Development: A Survey of Magma/Igneous Rock Systems. Routledge, Oxford.

Ozener, H., E. Arpat, S. Ergintav, A. Dogru, R. Cakmak, B. Turgut, Dogan, U., 2010. Kinematics of the Eastern Part of the North Anatolian Fault Zone, J Geodyn. 49 (34), 141-150.

Pasquarè F., Tibaldi, A., 2007. Structure of a sheet-laccolith system revealing the interplay between tectonic and magma stresses at Stardalur Volcano, Iceland. J. Volcanol. Geotherm. Res. 161, 131-150. 
Poidevin, J.L., 1998. Provenance studies of obsidian artefacts in Anatolia using the fission track dating method, An overview, in L'Obsidienne au Proche et Moyen Orient, du Volcan a' l'Outil, edited by A. Gourgaud, B. Gratuze, G. Poupeau, J.L. Poidevin and M.C Cauvin, BAR International Series Hadrian Books, vol. 738, pp. 105-156.

Reilinger, R. et al., 2006. GPS constraints on continental deformation in the Africa-ArabiaEurasia continental collision zone and implications for the dynamics of plate interactions, J Geophys Res. 111, B05411.

Sançar, C., Zabc1, C., Akyüz, H.S., Sunal, G., Villa, I.M., 2015. Distrubuted transpressive continental deformation: The Varto Fault Zone, eastern Turkey, Tectonophysics $\underline{661,}$ 99-111.

Sandvol, E., Turkelli, N., Zor, E., Gok, R., Bekler, T., Gurbuz, C., Seber, D., Barazangi, M., 2003. Shear wave splitting in a young continent-continent collision: An example from eastern Turkey. Geophys. Res. Lett. 30 (24), 8041-8059.

Sinton, J.M., Detrick, R.S., 1992. Mid-ocean magma chambers. J. Geophys. Res. 97, 197216.

Spence, D.A., Sharp, P.W., Turcotte, D.L., 1987. Buoyancy-driven crack propagation: a mechanism for magma migration. J. Fluid Mech. 174, 135-153.

Şengör, A.M.C., Tüysüz, O., Imren, C., Sakınç, M., Eyidogan, H., Görür, N., Le Pichon, X., Rangin, C., 2004. The North Anatolian Fault: a new look, Annu. Rev. Earth Planet. Sci. 33, 37-112.

Tan, O., Tapırdamaz, M.C., Yörük, A., 2008. The earthquake catalogues for Turkey. Turk. J. Earth Sci. 17 (2), 405-418. 
Tabatabaian, M., 2014. Comsol for Engineers. Mercury Learning and Information, Boston.

775

776

777

778

779

780

781

782

783

784

785

786

787

788

789

790

791

792

793

Tarhan, N., 1991. Hınıs-Varto-Karlıova (Erzurum-Muş-Bingöl) Dolayındaki Neojen Volkanitlerinin Jeolojisi ve Petrolojisi. MTA Dergisi 113, 1-15 (in Turkish).

Tatar, O., Piper J.D.A., Gürsoy, H., Heimann, A., Koçbulut, F., 2004. Neotectonic deformation in the transition zone between the Dead Sea Transform and the East Anatolian Fault Zone, southern Turkey: a palaeomagnetic study of the Karasu Rift Volcanism. Tectonophysics 385, 17-43.

Tibaldi A., 2015. Structure of volcano plumbing systems: A review of multi-parametric effects. J. Volcanol. Geotherm. Res. 298, 85-135.

Tibaldi A., L. Vezzoli, F.A. Pasquarè, Rust, D., 2008. Strike-slip fault tectonics and the emplacement of sheet-laccolith systems: The Thverfell case study (SW Iceland). J. Struct. Geol. 30, 274-290.

Vigneresse, J.L., 1999. Intrusion level of granitic massifs along the Hercynian belt: balancing the eroded crust. Tectonophysics 307, 277-295.

Williams, G.D., Powell, C.M., Cooper, M.A., 1989. Geometry and kinematics of inversion tectonics. In: Cooper, M.A., Williams, G.D. (Eds.), Geol. Soc. (Lond.) Spec. Publ. 44., pp. $3-$ 15.

Zienkiewicz, O. C., 1979. The Finite Element Method. McGraw-Hill, New York, p. 787. 


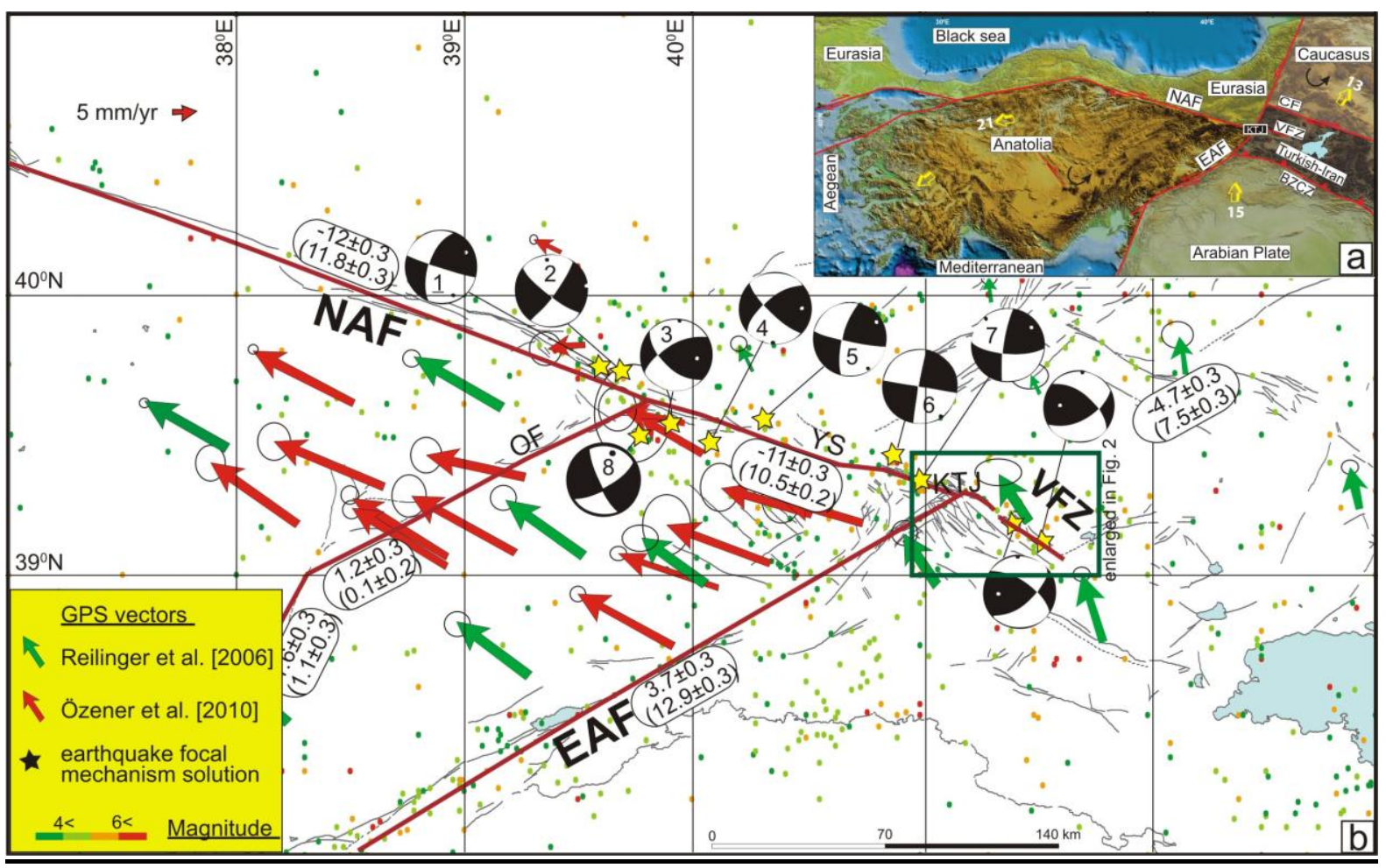

797 Figure 1. a) Major elements of crustal deformation in the eastern Mediterranean and Anatolia

798 (Armijo et al., 1999). NAF: North Anatolian Fault, EAF: East Anatolian Fault, BZCZ: Bitlis-

Karlıova Triple Junction; b) map showing GPS velocities with respect to Eurasia for 95\% confidence ellipses (green vectors are Reilinger et al., 2006; red vectors are Ozener et al., 2010; and the focal mechanism solutions from Tan et al., 2008 for the study area). Numbers represent strike-slip component of the fault in $\mathrm{mm} / \mathrm{year}$, numbers within parentheses represent normal component of the fault, red lines are block boundaries (Aktug et al., 2013). Seismic data are from KOERİ (http://udim.koeri.boun.edu.tr/zeqdb/). 


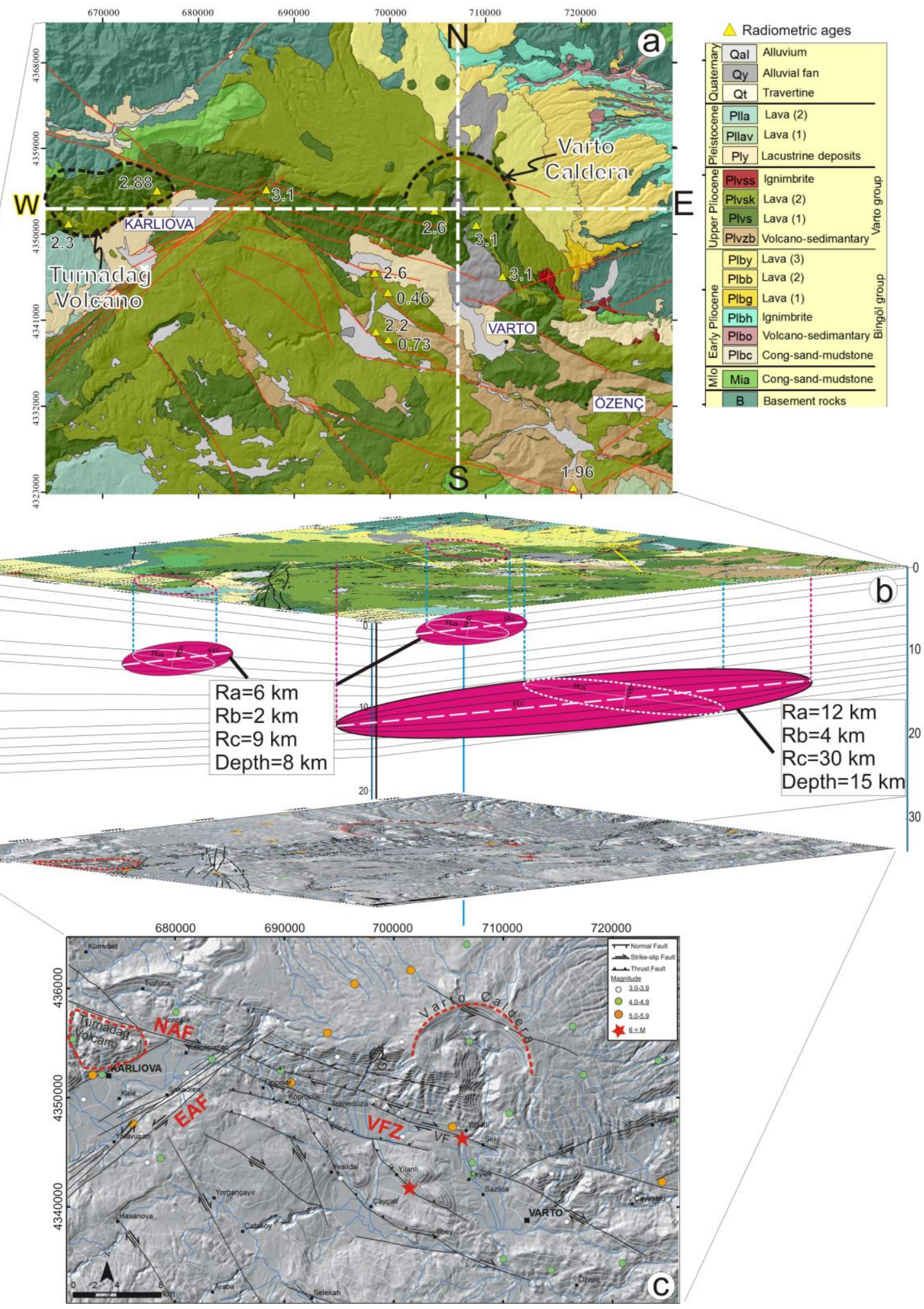

807 Figure 2. a) Geological map showing the main faults and seismicity around the Karlova and

808 Varto region. Radiometric ages are given in Ma. Active faults are modified from Herece and

Akay (2003) and Sançar et al. (2015). b) Magma chambers on the block model using a 
811 ( $R a, R b$ and $R c)$; c) Shaded relief basis map showing the main faults and seismicity around

812 the Karlıova and Varto regions. Active faults are modified from Herece and Akay (2003) and

813 Sançar et al. (2015). Seismicity data from KOERİ. NAF: North Anatolian Fault, EAF: East

814 Anatolian Fault, KTJ: Karlıova Triple Junction, VFZ: Varto Fault Zone, VF: Varto Fault; GF:

815 Güzeldere Fault. 

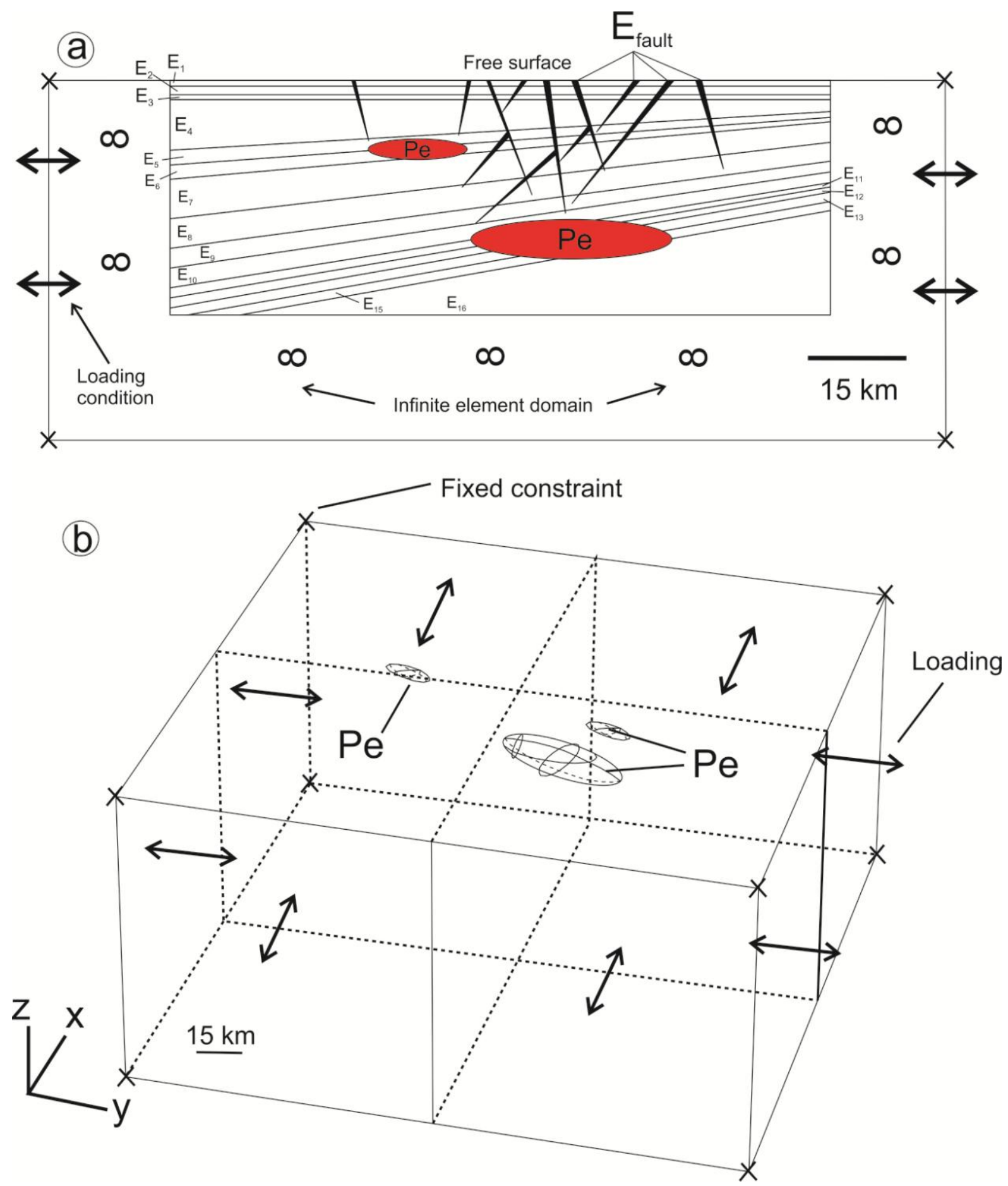

817 Figure 3. (a) 2-D and (b) 3-D numerical model setups. The 2-D example shown represents 818 the geology of a N-S striking profile through Varto caldera to the East of the KTJ. All 2-D 819 models are layered $\mathrm{E}_{(1-16)}$ with each unit assigned a different value of Young's modulus. The 820 dips of individual layers are based on field measurements. Faults $\left(\mathrm{E}_{\text {fault }}\right)$, shown as black 821 polygons, are represented by zones of low stiffness and assigned Young's modulus of 0.1 
$822 \mathrm{GPa}$. Magma chambers, represented as cavities, are given an excess pressure of 5 to $15 \mathrm{MPa}$.

823 Finally, boundary conditions such as extension or compression are assigned to the model

824 edges. All 3-D models assume a homogeneous crustal segment with a Young's modulus of $82540 \mathrm{GPa}$.
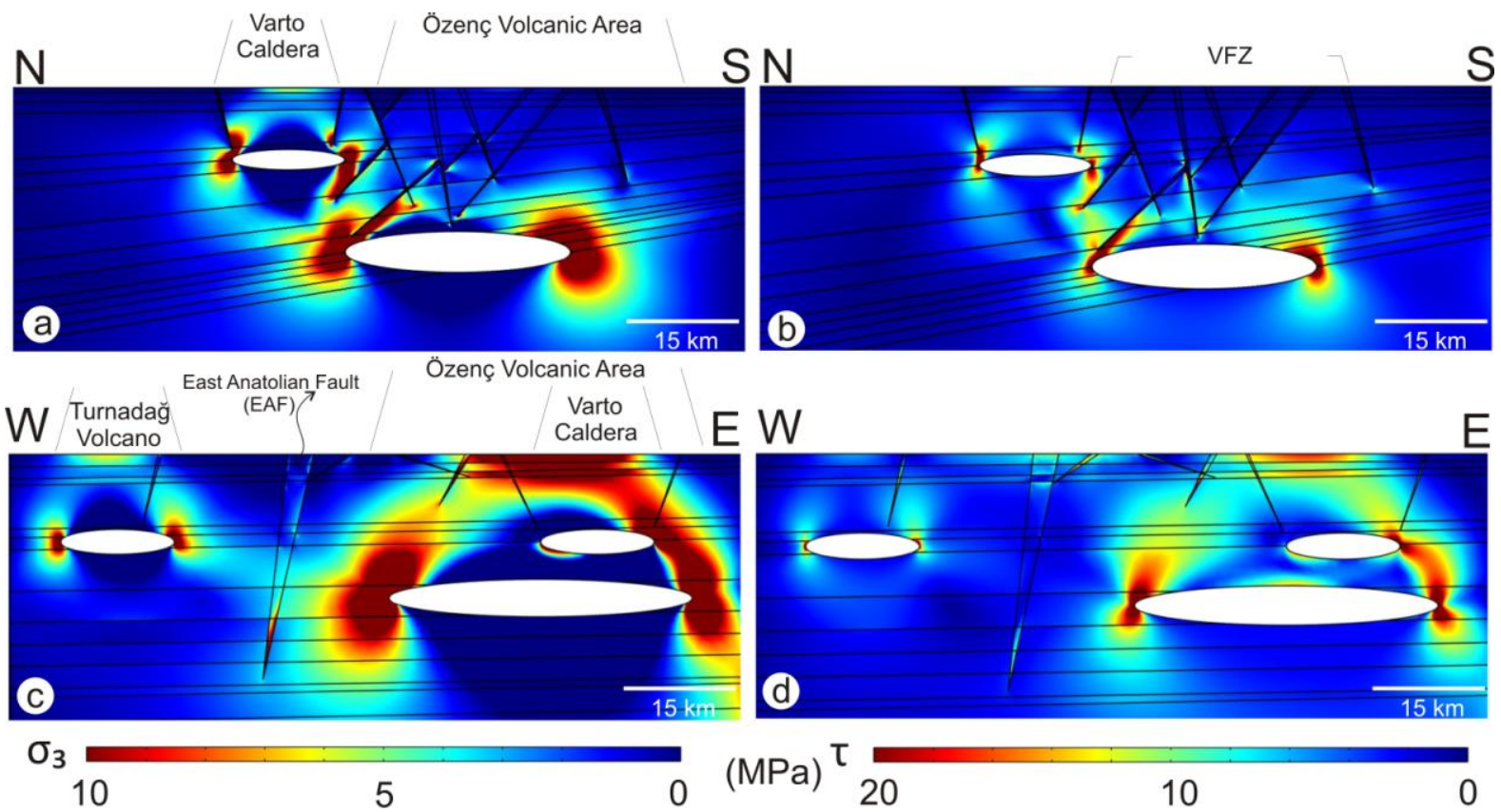

827 Figure 4. Modelled stresses induced by excess magmatic pressure based on the geologic

828 setting along the Northern Anatolian fault region. Left: Magnitudes of the minimum principal

829 compressive (maximum tensile) stress $\left(\sigma_{3}\right)$. Right: Magnitude of von Mises shear stresses $(\tau)$

830 The excess magmatic pressure in each chamber is $5 \mathrm{MPa}$ and is the only loading (no regional

831 tectonic loading is applied here). 

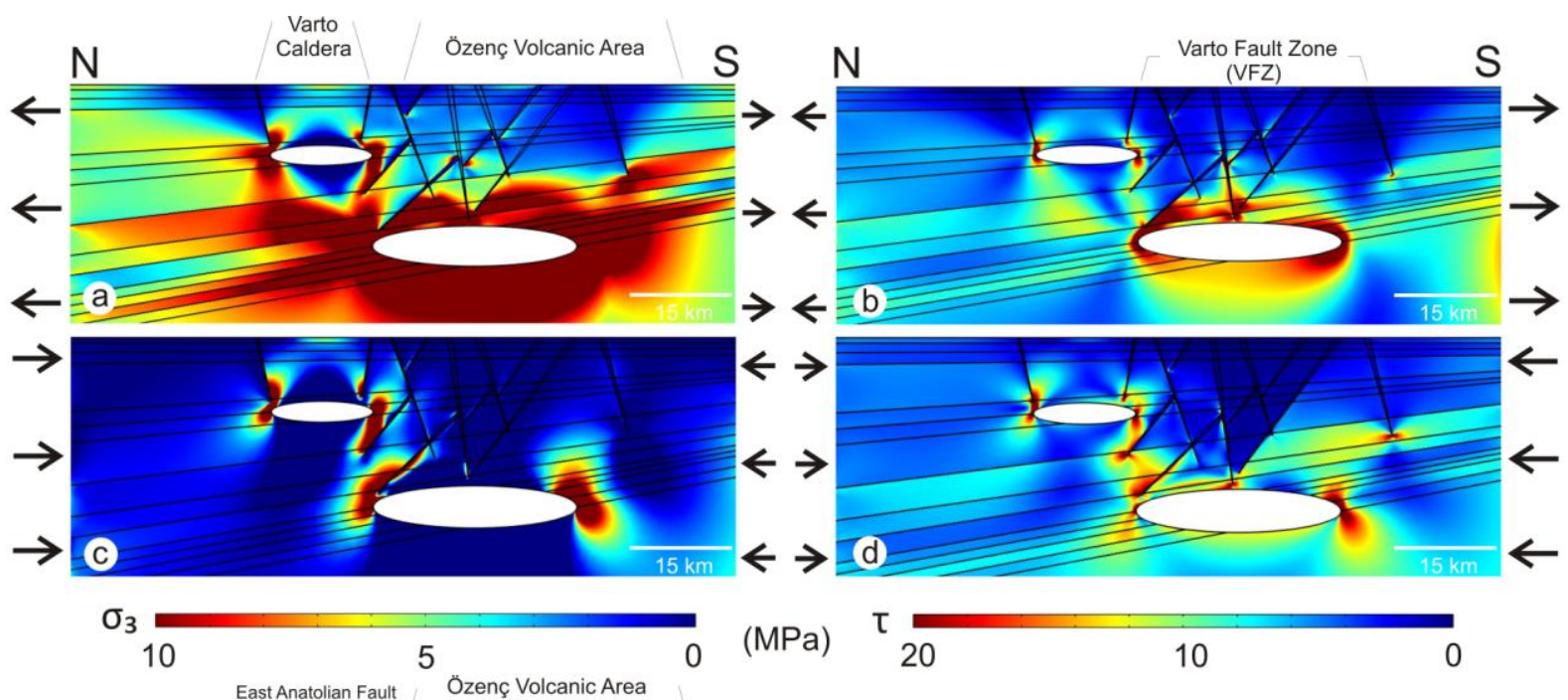

$(\mathrm{MPa})$
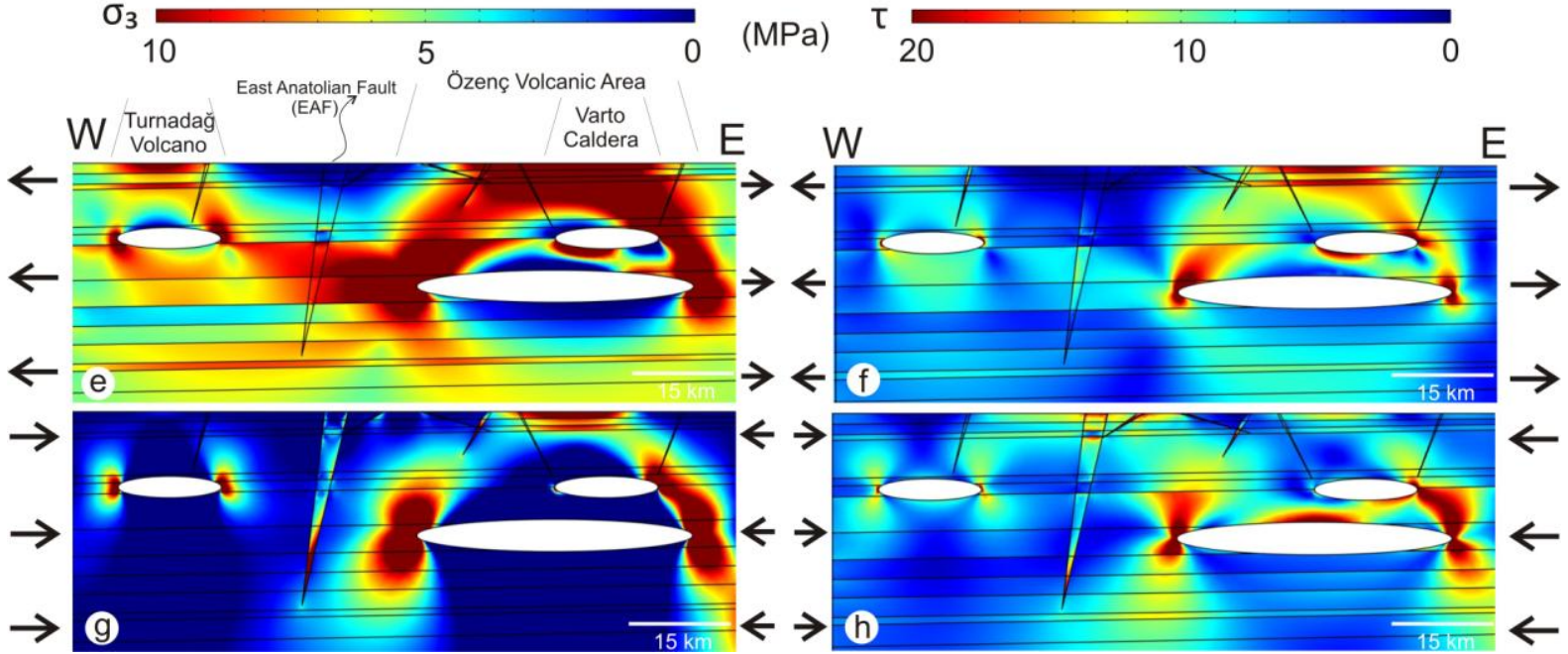

833 Figure 5. Modelled stresses resulting from regional tectonic extension ( $a-b$ and e-f) and

834 compression (c-d and g-h). Applied tensile and compressive boundary loads are $5 \mathrm{MPa}$ and

835 excess magmatic pressure is $5 \mathrm{MPa}$ in each chamber in all the models 

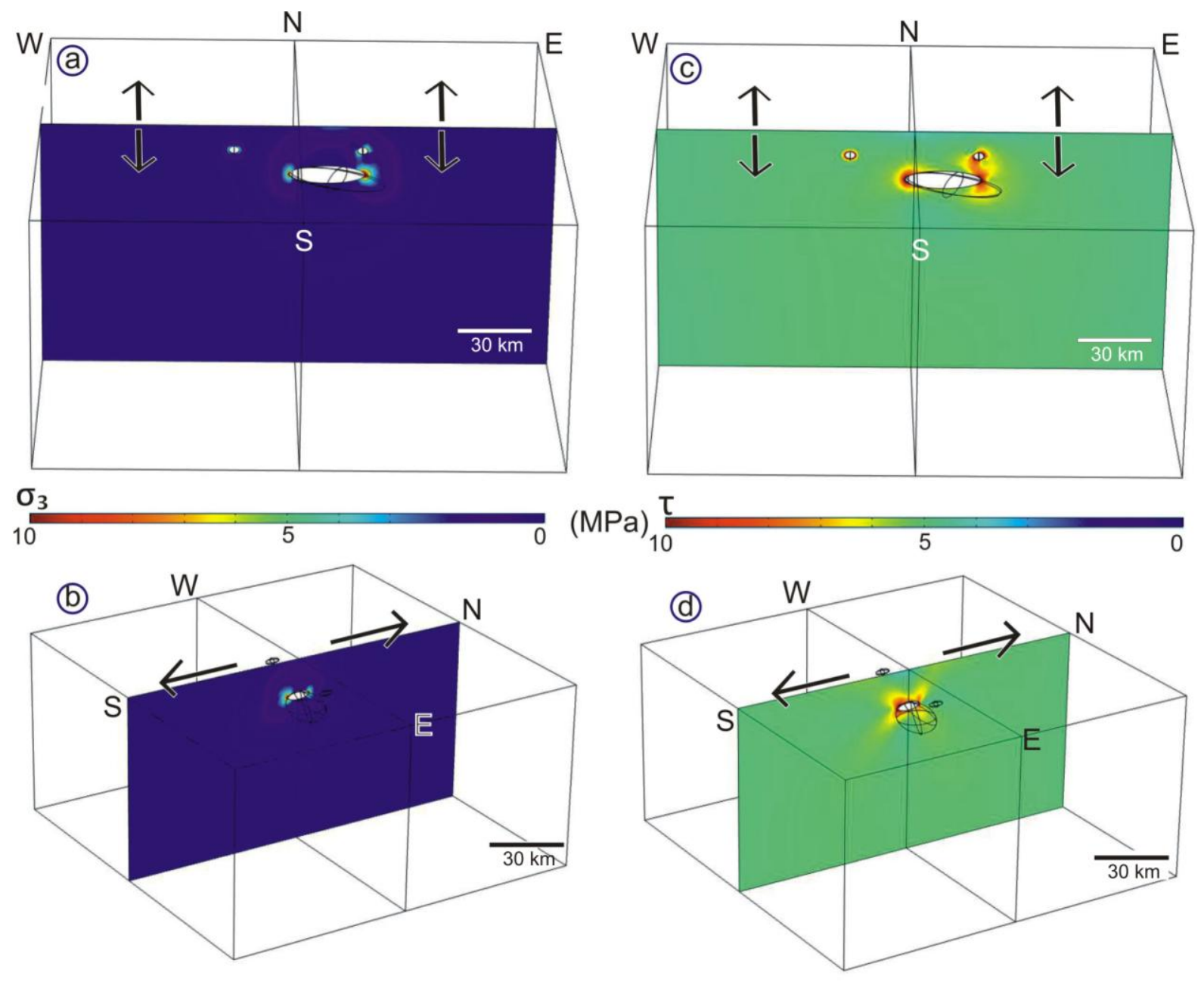

837 Figure 6. 3-D model showing the stresses resulting from tectonic extension from north to 838 south. Applied tensile and compressive boundary loads are $5 \mathrm{MPa}$ and excess magma 839 pressure is $5 \mathrm{MPa}$ in each chamber in all the models. a-b) Magnitudes of the minimum 840 principal compressive (maximum tensile) stress $\left(\sigma_{3}\right)$; c-d) Magnitudes of von Mises shear $841 \operatorname{stress}(\tau)$ 

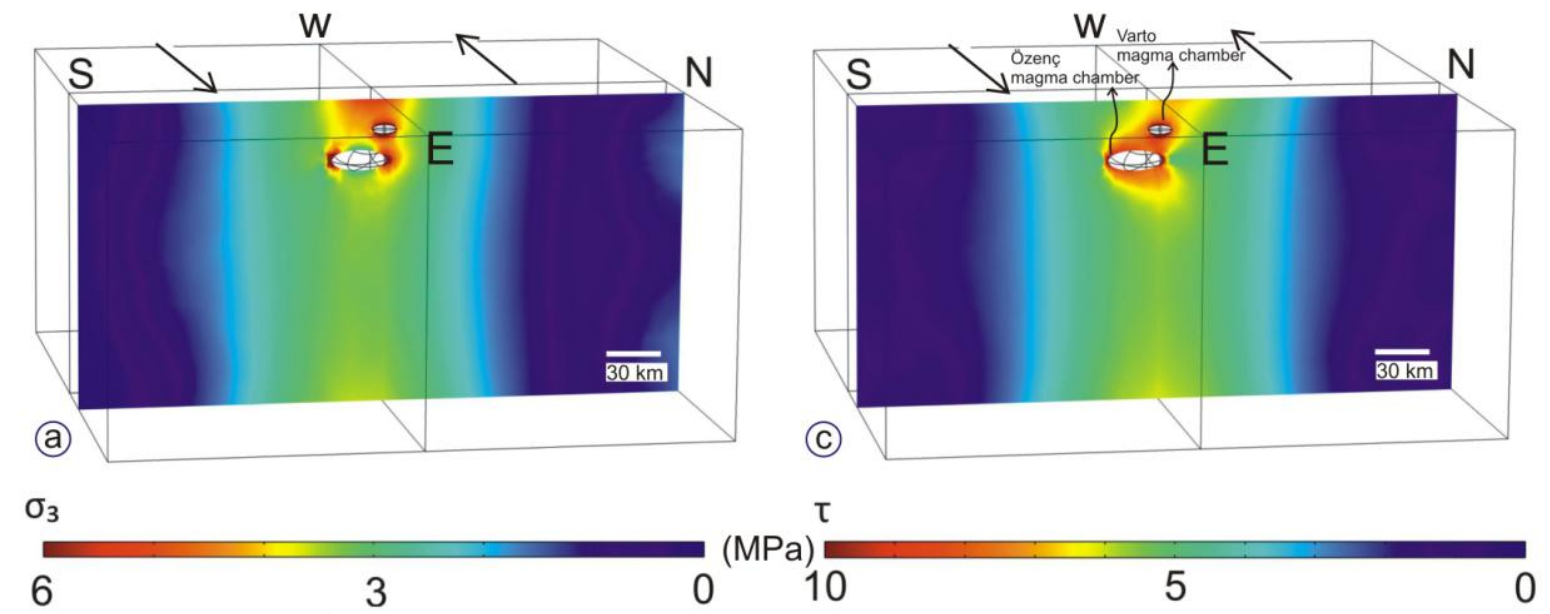

(b)

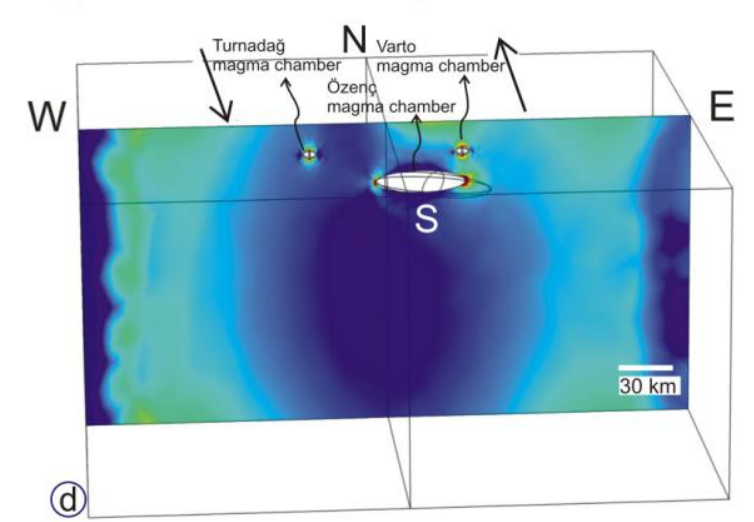

843 Figure 7. 3-D model showing the stresses resulting from an opposing boundary load 844 directions in a N-S direction. The eastern half of the model is subject to a $5 \mathrm{MPa}$ load to the 845 north, and the western half of the model subject to the same load to the south. Excess 846 magmatic pressure is $5 \mathrm{MPa}$ in each chamber in all models. a-b) Magnitudes of the minimum 847 principal compressive (maximum tensile) stress $\left(\sigma_{3}\right)$. c-d) Magnitudes of von Mises shear stress $(\tau)$. 

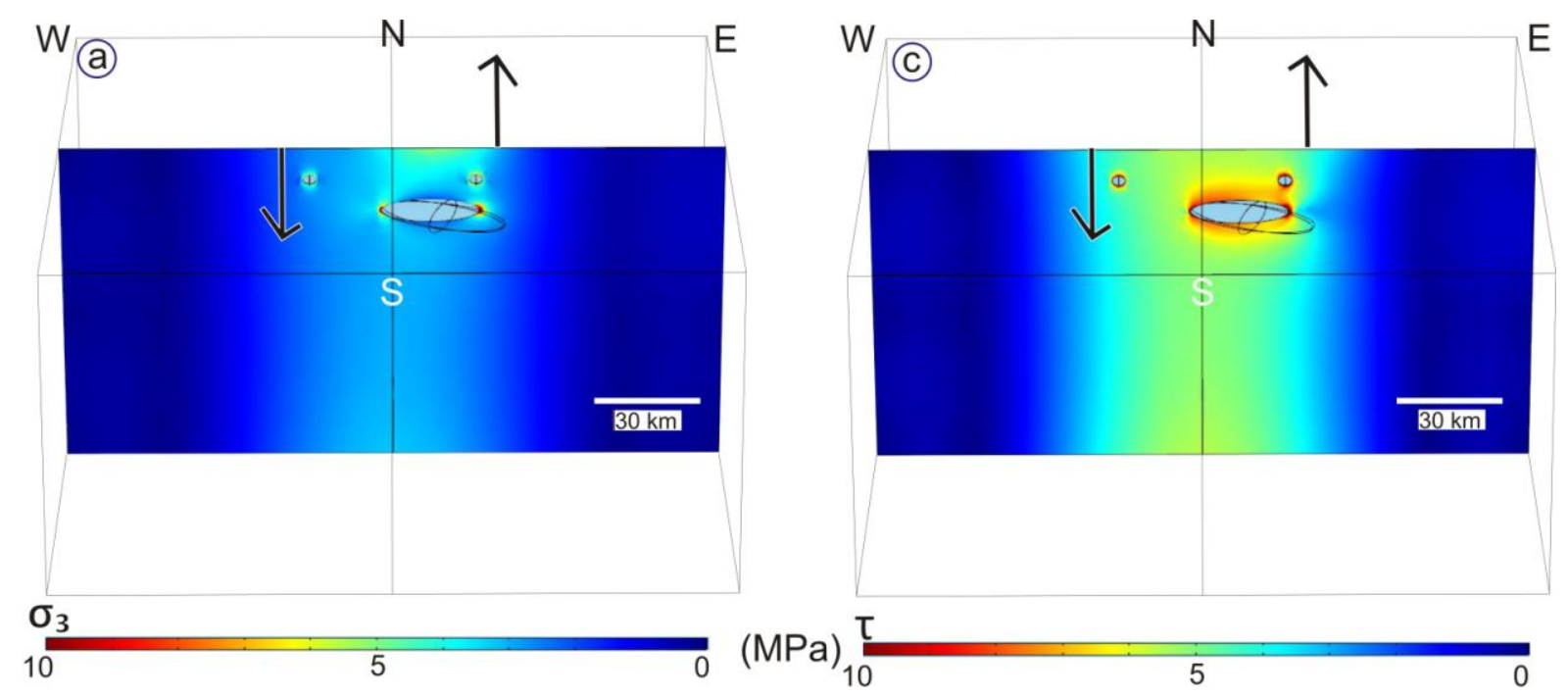

$(\mathrm{MPa})_{10}^{\mathrm{T}}$
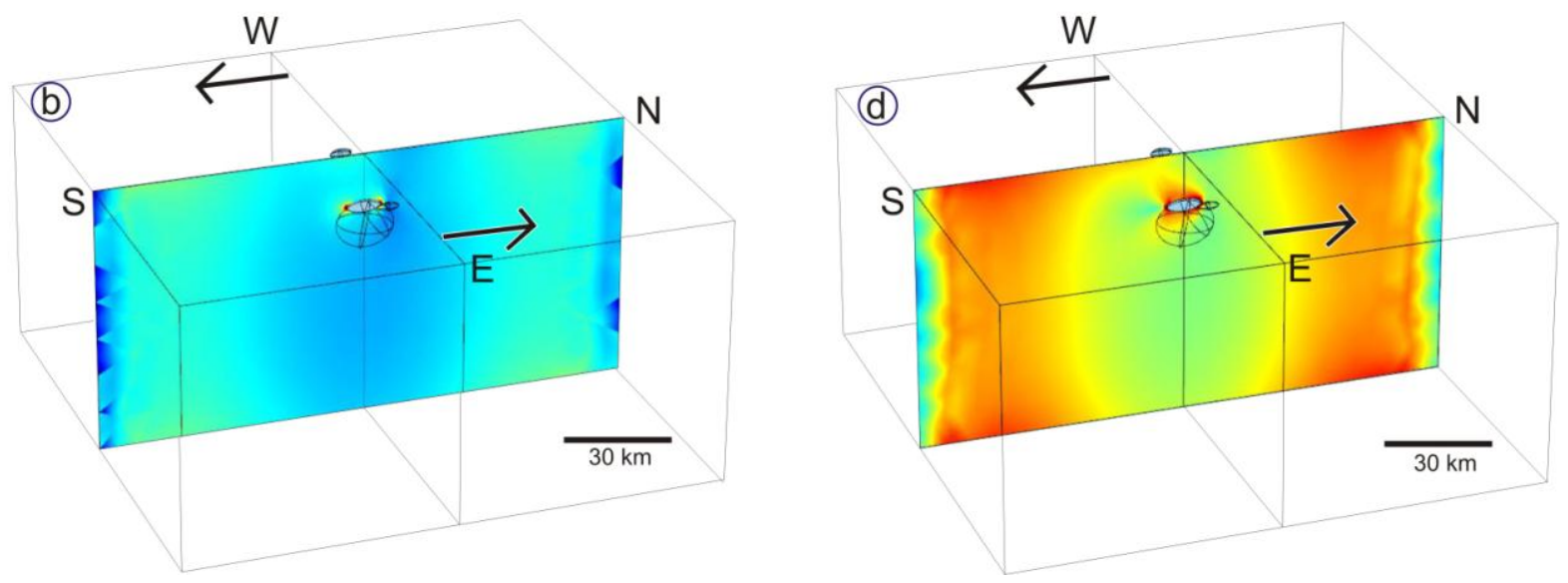

851 Figure 8. 3-D modelled stresses resulting from N-S-directed left-lateral tectonic shear

852 loading. Applied tensile and compressive boundary loads are 5 and excess magma pressure is

$8535 \mathrm{MPa}$ in each chamber in all the models. a-b) Magnitudes of the minimum principal

854 compressive (maximum tensile) stress $\left(\sigma_{3}\right)$. c-d) Magnitudes of von Mises shear stress $(\tau)$. 

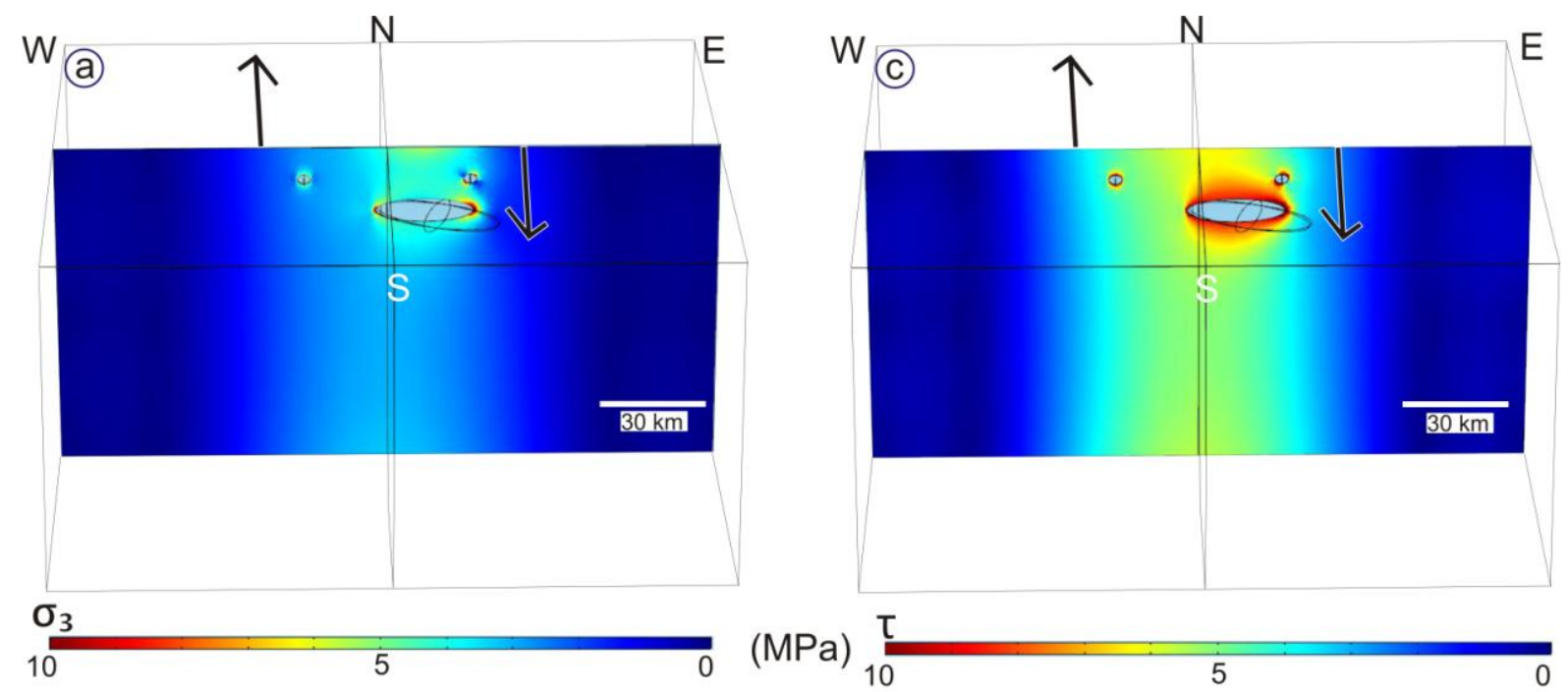

855
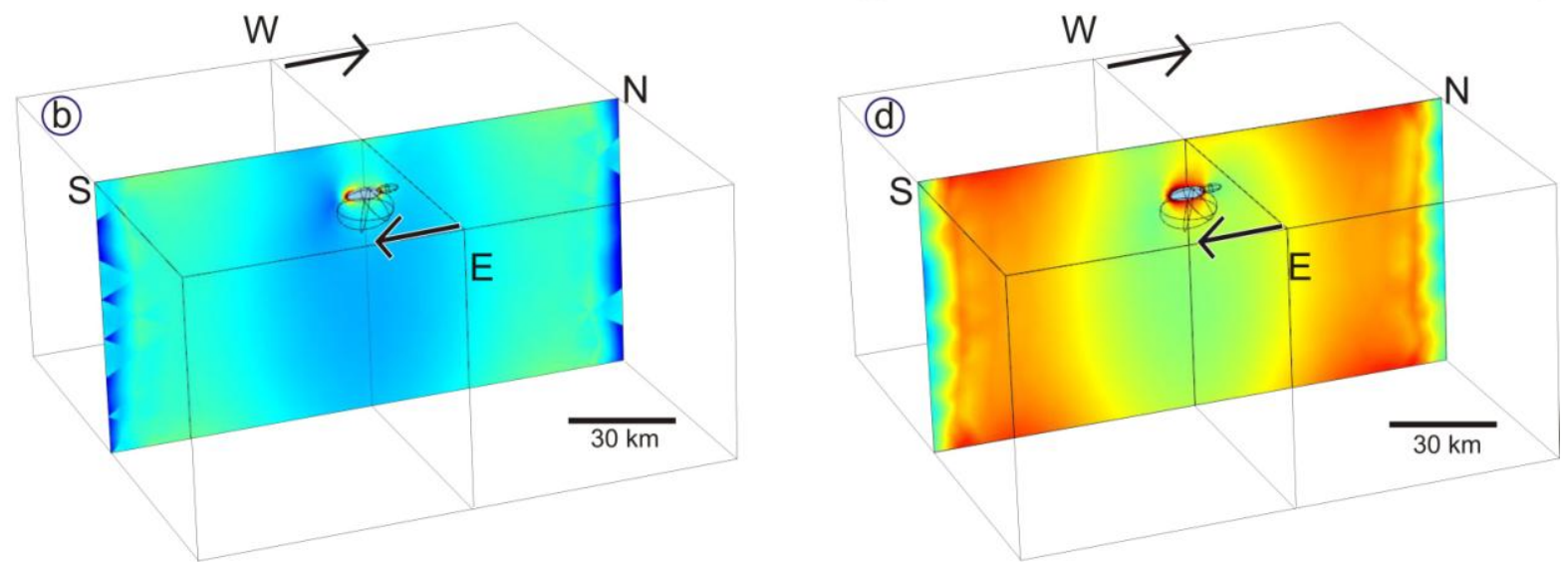

856 Figure 9. 3-D modelled stresses resulting from $\mathrm{N}$-S-directed right-lateral tectonic shear

857 loading. Applied tensile and compressive boundary loads are 5 and excess magmatic pressure

858 is $5 \mathrm{MPa}$ in each chamber in all models. a-b) Magnitudes of the minimum principal

859 compressive (maximum tensile) stress $\left(\sigma_{3}\right)$. c-d) Magnitudes of von Mises shear stress $(\tau)$. 

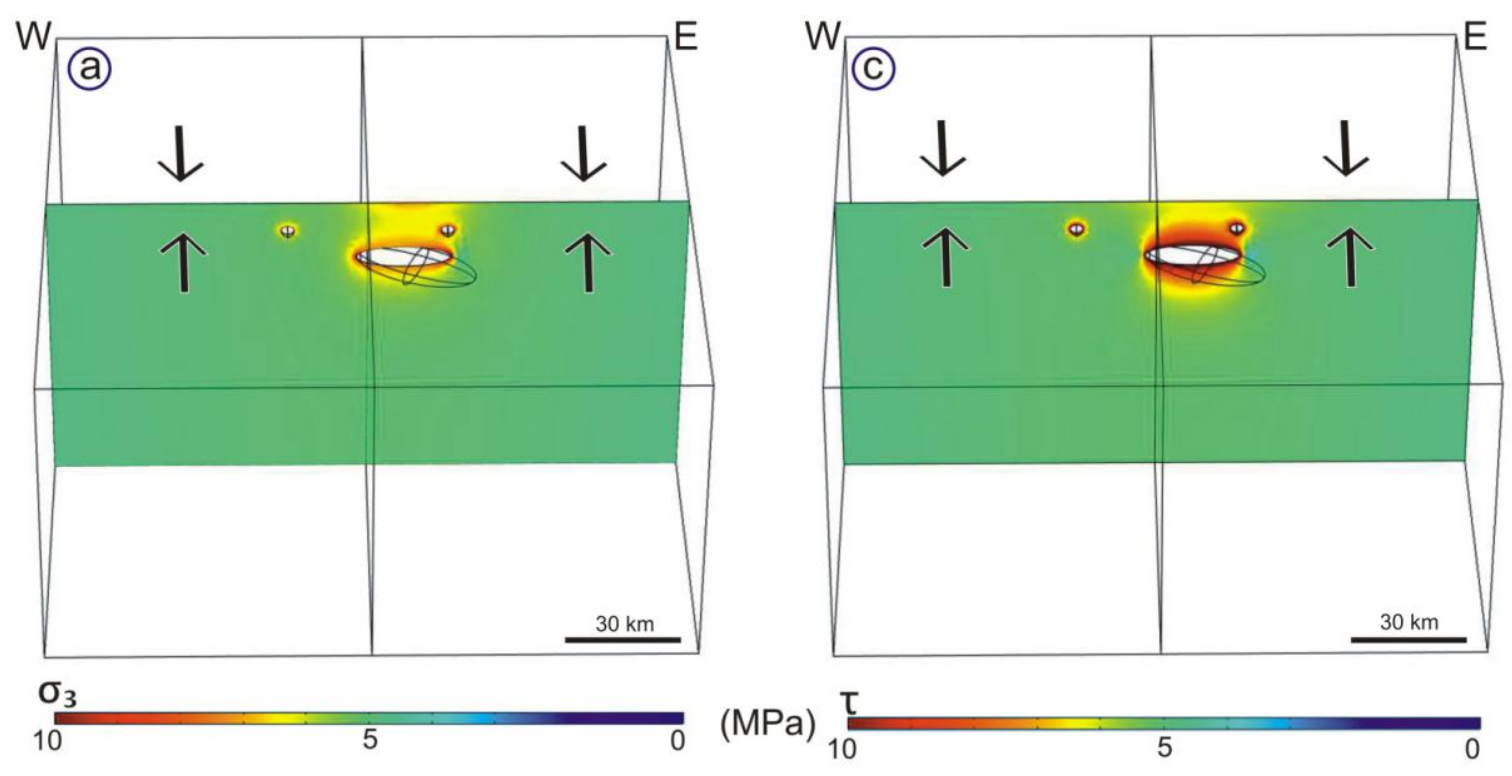

860
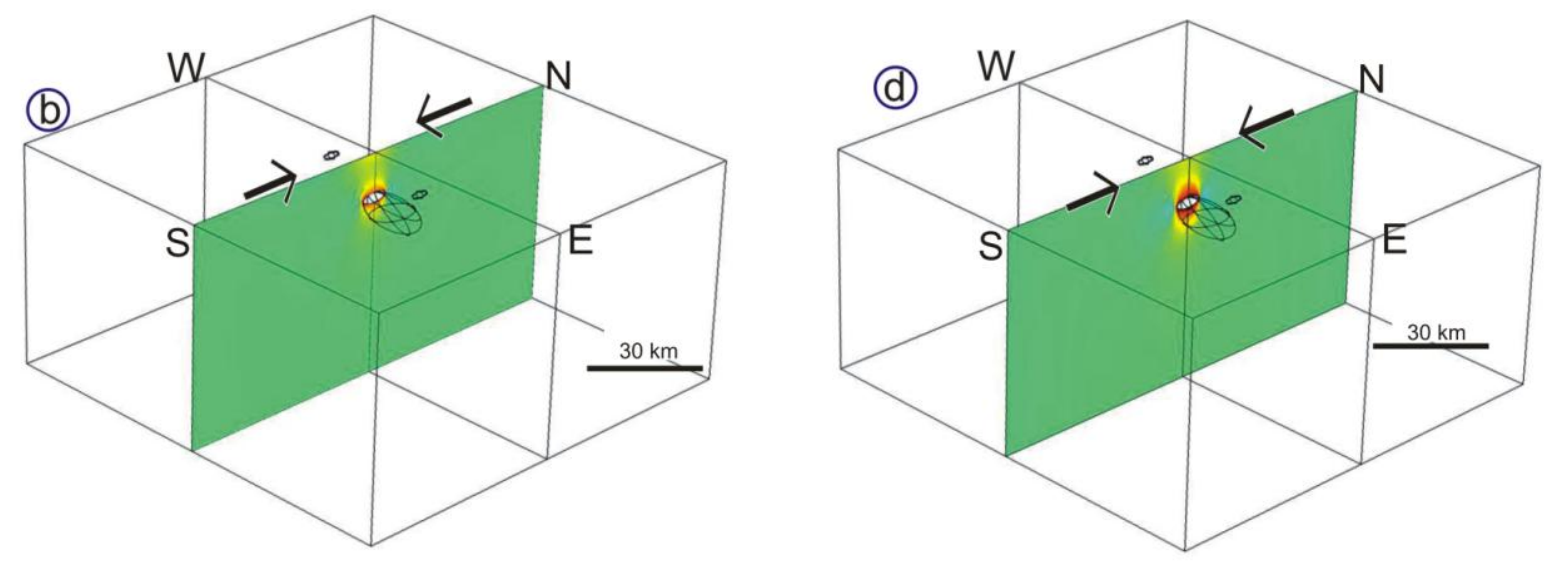

861 Figure 10. 3-D modelled stresses resulting from tectonic compression from north to south.

862 Applied tensile and compressive boundary loads are 5 and excess magmatic pressure is 5

$863 \mathrm{MPa}$ in each chamber in all the models. a-b) Magnitudes of the minimum principal 864 compressive (maximum tensile) stress $\left(\sigma_{3}\right)$. c-d) Magnitudes of von Mises shear stress, $\sigma_{1}-\sigma_{3}$. 